\title{
sciforum
}

Conference Proceedings Paper

\section{Diurnal Cycle of convection in the Peruvian Highlands}

\author{
Eleazar Chuchón ${ }^{1 *}$, Augusto Pereira ${ }^{2}$ \\ Published: 12/11/2017 \\ Academic Editor: Anita Drumond \\ 1 Universidad Nacional de San Cristobal de Huamanga, Perú; eleazar.angulo@alumni.usp.br \\ 2 Universidade de Sao Paulo, Brazil ; augusto.pereira@iag.usp.br \\ *Correspondence: eleazar.angulo@alumni.usp.br , Tel.: +51-939578255
}

\begin{abstract}
This manuscript examines from the diurnal convection cycle (CDC) to the interdecadal variability in the region of the Peruvian Altiplano (RAP). Currently, estimating precipitation using satellites is an alternative which can be used to study the spatio-temporal evolution of precipitation systems. Herein CPC data Morphing technique - CMORPH was used between 2002 and 2014 to analyze the CDC in RAP. The CMOPRH data were compared with rainfall data series measured by rain gauges of meteorological stations (EMS) in the RAP. The results indicate that the CDC shows high variability in the Titicaca Basin and is associated with patterns of lake breeze (day), land breeze (night) and mountain - valley circulation. The CDC starts at $1800 \mathrm{HL}$ (local time) in the northern region of Lake Titicaca, lasting between $2 \mathrm{~h}$ and $6 \mathrm{~h}$, and most of $2000 \mathrm{HL}$. The CDC over the dry surface (ST) of Titicaca Basin starts early at around $1200 \mathrm{HL}$, lasting $4 \mathrm{~h}$ to $7 \mathrm{~h}$, and maximum at 1800 HL.
\end{abstract}

Keywords: CMORPH; CDC; Titicaca Lake

\section{Introduction}

The Peruvian Altiplano Region (PAR), is a geographical area of high plateau morphology, located on the 3810 meters of altitude. It is surrounded by the western and eastern ranges of the Andes, and the drainage is part of a great fluvial system, integrated with the basins Poopó, Coipasa, and Uyuni, all of which have acommon collector in Lake Titicaca (LT) [1] (Figure 1).

Used the HadRM3 and ETA CSS models to simulate temperature in two scenarios: A2 (High concentration and CO2) and B2 (Low CO2 concentration), temperatures increase between $2^{\circ} \mathrm{C}$ to $4^{\circ} \mathrm{C}$, and to a maximum value of $6^{\circ} \mathrm{C}$, in the northern region of Lake Titica by the year 2100. Unlike temperature trends, whih are clear [2]. Rainfall may decrease slightly over the PAR, but the patterns are not clearly defined. For example, in austral summer, in the southwestern part of the TL, a decrease of the precipitation up to $6 \mathrm{~mm} /$ day is observed [2]. However, observed trends show systematic precipitation increases in the western RAP slope as well as reductions in the eastern, southern and central slopes $[3,4]$. 
The 1st International Electronic Conference on Hydrological Cycle (CHyCle-2017), 12 - 16 November 2017; Sciforum Electronic Conference Series, Vol. 1, 2017

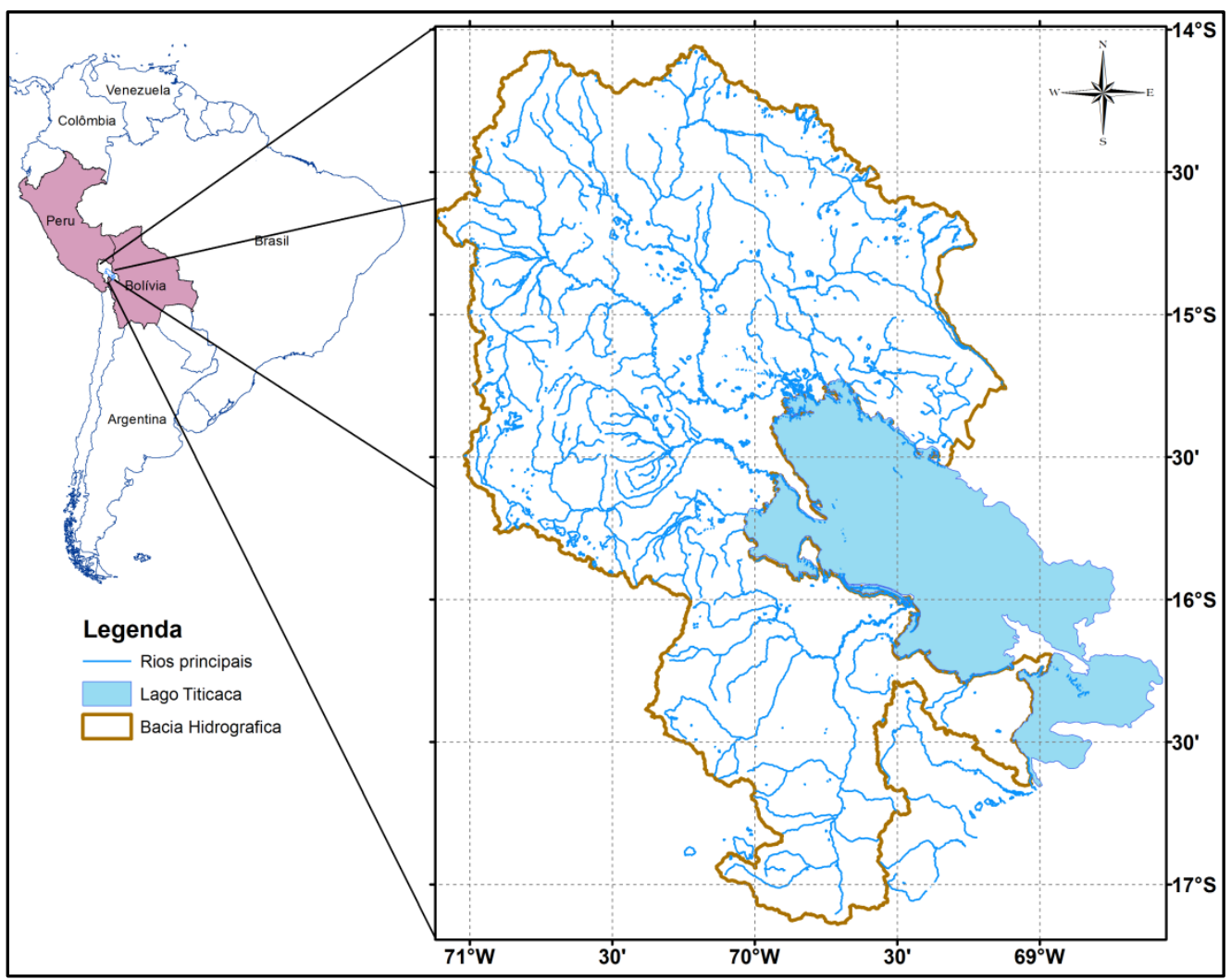

Figure 1. Map of the location of the Lake Titicaca Basin in South America (detail on the left). The drainage red, surface of the lake, latitudes and longitudes and geographical contours are indicated. 2015.

Figure 2 shows the variability of the LT bottom, according to Blanco et al [5], the greatest depths are found in the northern region, with a maximum value of $275 \mathrm{~m}$. The extension and the volume of storage are: $8400 \mathrm{~km} 2$ and 932.000 million cubic meters respectively, according to the information granted by the Binational Authority of Lake Titicaca (ALT).

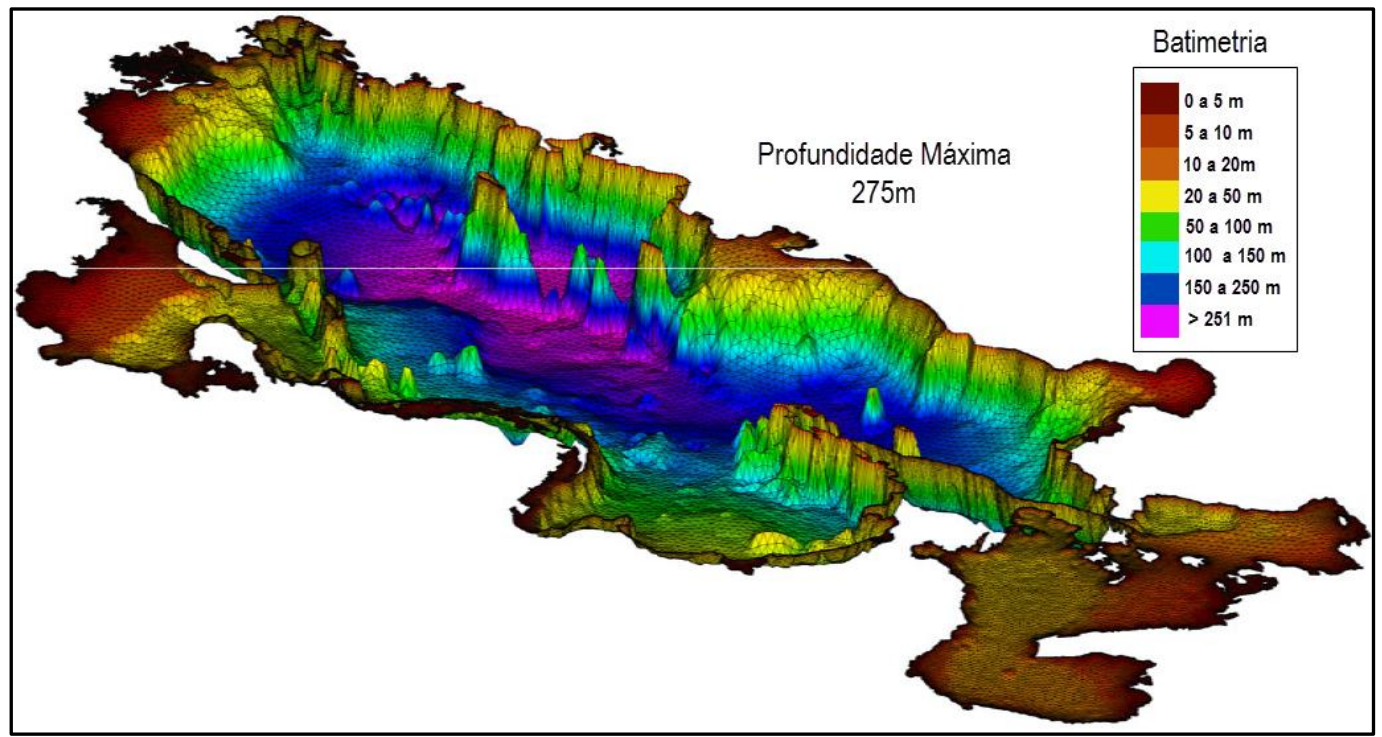

Figure 2. Bathymetry of Lake Titicaca, the scale in colors represents depth in meters. Adapted from Blanco et al. [5]. 
The 1st International Electronic Conference on Hydrological Cycle (CHyCle-2017), 12 - 16 November 2017; Sciforum Electronic Conference Series, Vol. 1, 2017

The topography of the LT basin is typical of a mountain basin, where the portion of the Altiplano is mostly covered by the lake water (Figure 3), which is surrounded by the Eastern and Western Cordilleras. The eastern slope is quite irregular, with moderate to high slopes, the western slope has moderate to moderate slopes and mountains interspersed with very low peaks compared to the eastern mountain range where the maximum altitude is $4431 \mathrm{~m}$.

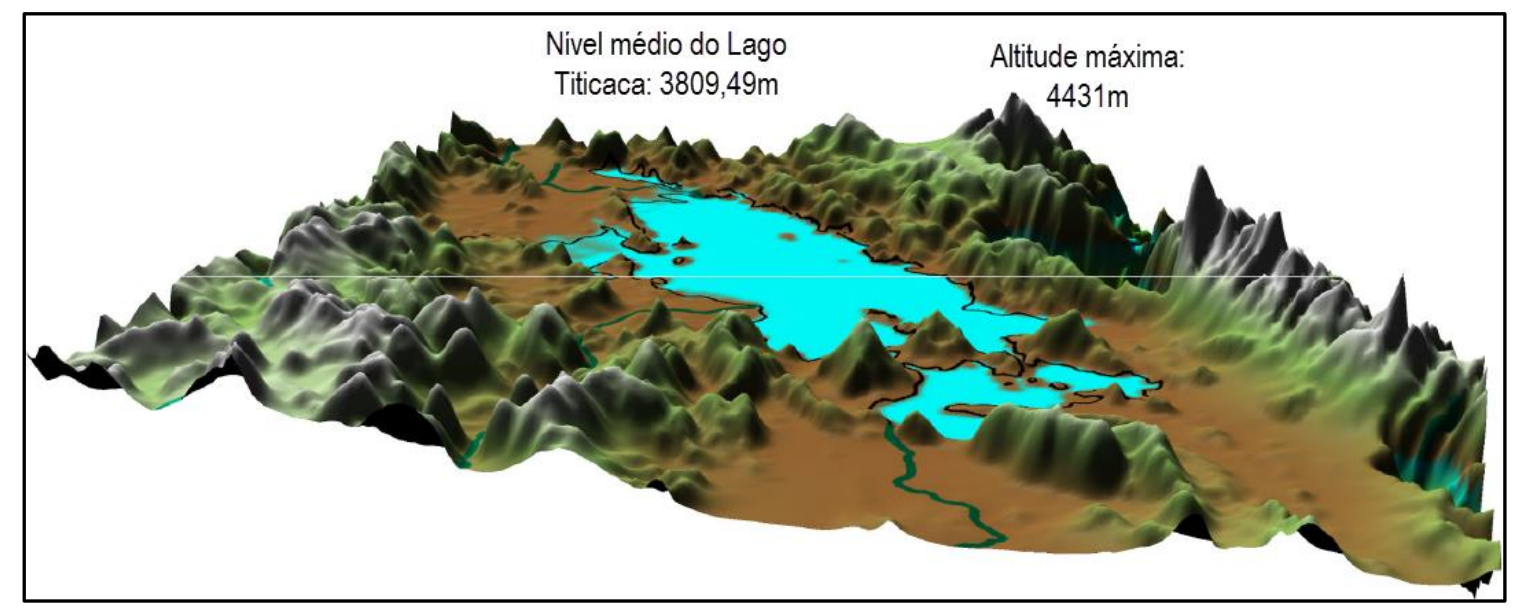

Figure 3. Elevation map of the Lake Titicaca basin. The Eastern Cordillera stands out for having the highest altitudes that reach up to $4431 \mathrm{~m}$. Extracted from Blanco et al. [5].

The lake is supplied by rainfall (47\%) and river water (35\%), mainly by the river Ramis [6]. The lake loses water by evaporation (91\%) and at the control point in the Desaguadero River (9\%), the average annual temperature in the lake basin fluctuates between 7 and $10^{\circ} \mathrm{C}$ [6].

Drought is an extreme global climate event with major societal and economic consequences for millions of people in the world, especially in arid and semi-arid regions[7,8]. How patterns of drought are changing as the climate changes has been the focus of several recent studies, but the answer remains unclear.

The main objective of the study is to study and understand the development of the CDC in the Lake Titicaca basin in order to contribute to the prediction of severe precipitation events in regions that do not have weather stations. Based on high spatio-temporal resolution data from the CPC Morphing Technique - CMORPH, Joyce et al [9], for the period 2002-2014.

\section{Experiments}

To carry out the CDC study, the period between January 2002 and February 2014 was chosen (according to the availability of CMORHP data). Based on this period, associated events were selected with intense convective systems and analyzed with the outputs of the Advanced Regional Prediction (ARPS) model. The objective was to better understand the development of convective events in the PAR and the LT.

The observed precipitation data (OPData) registered in the surface stations that are distributed in the PAR were also used. The selected period is the same period as the CMORPH data. The objective was to compare with the data from the CMORPH on a seasonal and annual basis. 
The 1st International Electronic Conference on Hydrological Cycle (CHyCle-2017), 12 - 16 November 2017; Sciforum Electronic Conference Series, Vol. 1, 2017

Table 1. General data analyzed of the meteorological network of the Peruvian Altiplano

\section{Station}

Latitude Longitude Elevation Station

Latitude Longitude Elevation

\begin{tabular}{llllllll}
\hline Ananea & $-14,68$ & $-69,53$ & 4660,0 & Juliaca & $-15,47$ & $-70,17$ & 3820,0 \\
Arapa & $-15,14$ & $-70,12$ & 3920,0 & Lagunillas & $-15,77$ & $-70,66$ & 4250,0 \\
Ayaviri & $-14,88$ & $-70,59$ & 3920,0 & Lampa & $-15,44$ & $-70,21$ & 3900,0 \\
Azangaro & $-14,91$ & $-70,19$ & 3863,0 & Laraqueri & $-16,15$ & $-70,07$ & 3970,0 \\
Cabanillas & $-15,64$ & $-70,35$ & 3890,0 & Llally & $-14,95$ & $-70,90$ & 4111,0 \\
Capachica & $-15,62$ & $-69,84$ & 3819,0 & Los Uros & $-15,80$ & $-69,92$ & 3808,0 \\
Chuquibambilla & $-14,80$ & $-70,73$ & 3910,0 & Mazo Cruz & $-16,75$ & $-69,71$ & 3970,0 \\
Cojata & $-15,02$ & $-69,36$ & 4344,0 & Muñani & $-14,78$ & $-69,97$ & 4119,0 \\
Crucero & $-14,36$ & $-70,02$ & 4130,0 & Pampahuta & $-15,49$ & $-70,68$ & 4320,0 \\
Desaguadero & $-16,57$ & $-69,04$ & 3860,0 & Pizacon a & $-16,92$ & $-69,37$ & 3940,0 \\
Huancane & $-15,20$ & $-69,76$ & 3860,0 & Progreso & $-14,69$ & $-70,36$ & 3905,0 \\
Huaraya Moho & $-15,39$ & $-69,49$ & 3890,0 & Pucara & $-15,03$ & $-70,37$ & 3885,0 \\
Ilave & $-16,08$ & $-69,64$ & 3850,0 & Puno & $-15,82$ & $-70,02$ & 3840,0 \\
Isla Soto & $-15,56$ & $-69,49$ & 3853,0 & Putina & $-14,91$ & $-69,87$ & 3878,0 \\
Isla Suana & $-16,34$ & $-68,86$ & 3845,0 & Santa Rosa & $-14,63$ & $-70,80$ & 3940,0 \\
Isla Taquile & $-15,78$ & $-69,69$ & 3815,0 & Tahuaco & $-16,31$ & $-69,07$ & 3860,0 \\
Juli & $-16,20$ & $-69,46$ & 3825,0 & Taraco & $-15,31$ & $-69,98$ & 3820,0 \\
\hline
\end{tabular}

\subsection{Analysis of observed data}

The series of observed data includes the data of historical series of measurements in rain gauges and rainfall recorders in the RAP, which were selected according to spatio-temporal availability.

The preliminary survey of the rainfall posts in the RAP showed that in an area of $61,102 \mathrm{~km} 2$ there were 43 rain gauge stations, which gives an idea on average, one station every $1420 \mathrm{~km} 2$. Therefore, this calculation does not consider the analysis of data availability in each position for the period compatible with the CMORPH data. Once the selection was made, 34 stations remained (Figure 4.), consequently, the area increased by each station to approximately $1780 \mathrm{~km} 2$. What evidences a picture of extreme deficiency and according to the reconmendation made by the World Meteorological Organization (WMO, 1994), is $575 \mathrm{~km} 2$ per position, in the case of regions with mountainous / flat relief. 


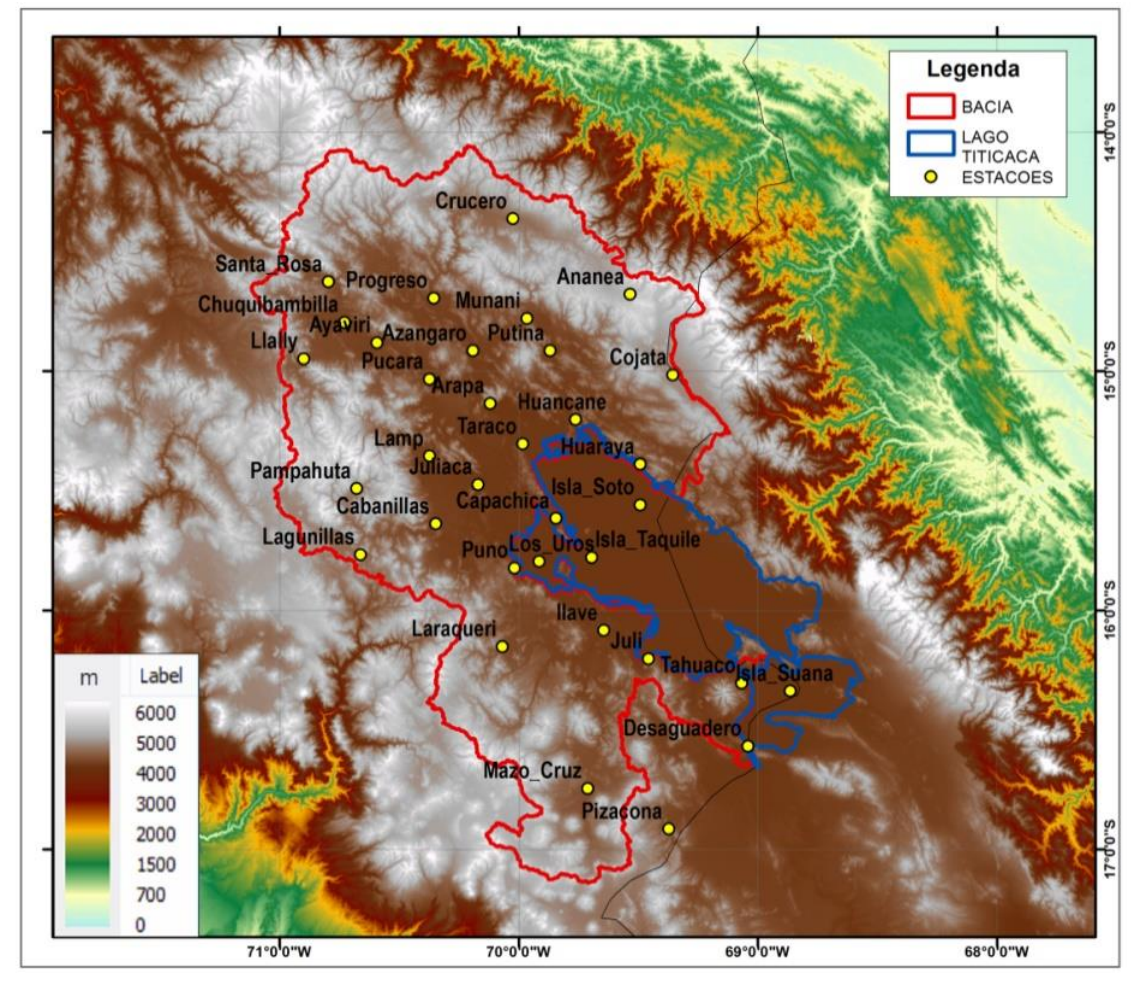

Figure 4. Location of the pluviometric points with their respective names that were used in the analysis of the annual rainfall regimen. Scale of colors represents the topography $(\mathrm{m})$ of the study area. The red line represents the TL basin and the blue color represents the TL. Vertical axis indicates latitudes and horizontal axis refers to lengths, both in degrees $\left(^{\circ}\right)$.

\subsection{Analysis of precipitation estimates in $\mathrm{CMORPH}$}

In this work, the series of precipitation estimates derived from the CMORPH for the period from January 2002 to February 2014 were analyzed, in order to recompose the precipitation field of the CMORPH and to explain graphically the CDC in the PAR.

Maps of precipitation estimates were generated for 24 hours (at a time level), to observe the formation and development of convective events for the austral summer. The maps were generated in three domínios: (a) region of the Andes mountain range, (b) the Altiplano region and (c) the TL basin. Figure 5 .

\subsection{Statistical tests}

Due to the complexity of the precipitation, there are several statistics that allow the accuracy to be evaluated whether a certain estimate is good or not. Consequently, in this work, the evaluation is given by a set of statistics.

According to what was exposed for the observed and estimated rainfall data, conventional statistics were calculated, such as average, maximum, standard deviation and graphs, such as histograms, spatialization maps of observed and estimated rainfall, and even comparisons between rainfall and rainfall. .

The evaluation by quantitative statistics was applied in the point-to-point comparison and in the analysis between the specialized areas of data estimated and observed in each of the 34 stations in the PAR. The point-to-point comparative analysis is a direct comparison between the series observed 
in the pluviometric position and the series generated by the CMORPH estimator in the pixel in which the station is located, remembering that each pixel has approximately $49 \mathrm{~km} 2$. By virtue of being a direct method, in which the series estimated in the pixel is compared with the series of the respective position, it serves for a preliminary analysis, because it has a tendency to present results with correlations ( $\mathrm{r}$ ) inferior to the interpolation method. This is due to the fact that the rainfall is a point estimate, while the CMORPH represents an average estimate in the pixel.

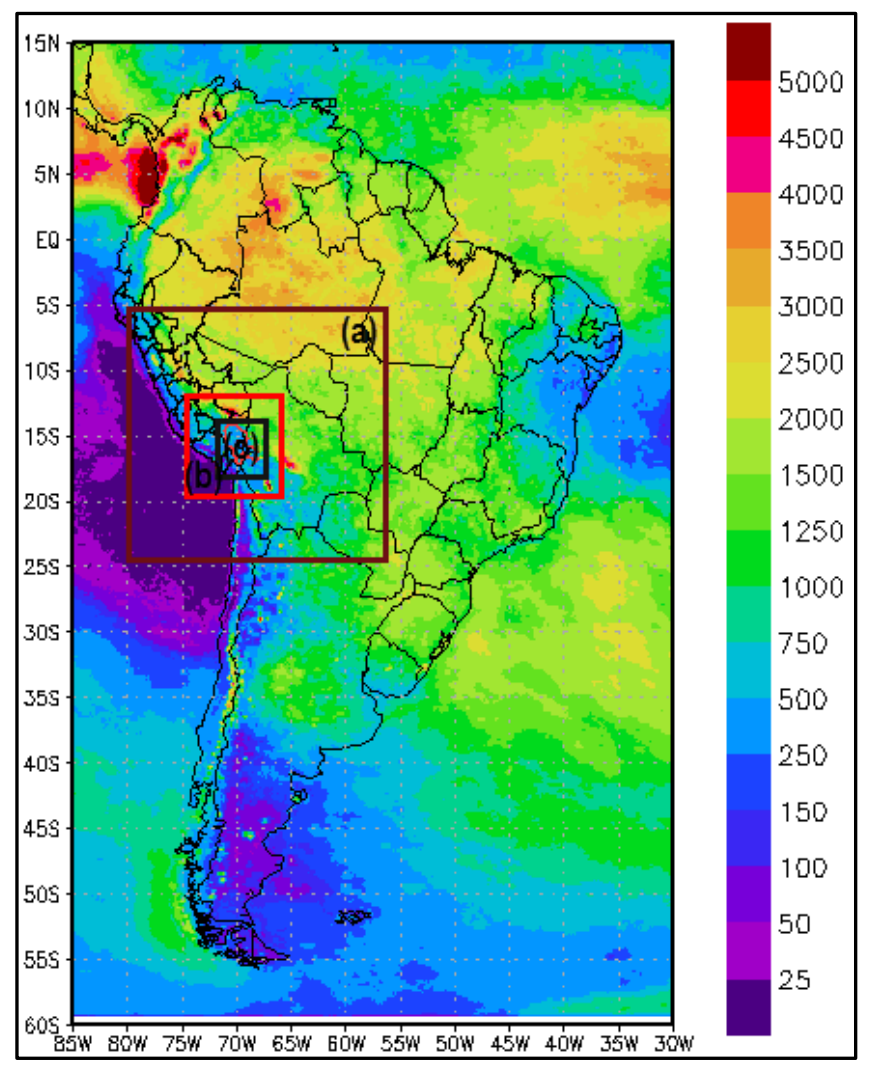

Figure 5. Accumulated annual accumulated precipitation for 2008 generated from the CMORPH data. The region defined by the brown color envelops the Peruvian and Bolivian Andes. The red color indicates the Altiplano region (Peru and Bolívia). The black color represents the Lake Titicaca River Basin. The scale in colors represents the precipitation estimates in millimeters ( $\mathrm{mm})$. Vertical axis indicates the latitudes and the horizontal axis refers to the lengths, both em degrees $\left(^{\circ}\right)$.

\subsection{Calculation of the Bias}

To evaluate the quality of the CMORPH data, the average bias for the austral summer for each surface station and the CMORPH data in the selected period was calculated. The mathematical definition of the bias is the following:

$$
\text { bias }=\frac{1}{N} \sum_{I=1}^{N}\left(P_{i}-O_{i}\right)
$$

Where $\mathrm{N}$ is the number of months; $\mathrm{Pi}$ is the value of the $\mathrm{CMORPH}$ at the grid point valid for a certain instant and for a specific observation station; Oi is the corresponding observed value. The bias calculation is quite simple and intuitive; if the range of values varies from $+\infty$ to $-\infty$ adjust equal to zero. 
The 1st International Electronic Conference on Hydrological Cycle (CHyCle-2017), 12 - 16 November 2017; Sciforum Electronic Conference Series, Vol. 1, 2017

\subsection{Correlation coefficient}

Equation 2 represents the linear association between rainfall estimates by CMORPH and rainfall.

$$
r=\frac{\sum_{i=1}^{n}(P i-P)(Z i-Z)}{\sqrt{\sum_{i=1}^{n}(P i-P)^{2}} \sqrt{\sum_{i=1}^{n}(Z i-Z)^{2}}}
$$

Pi being the precipitation observed at time $\mathrm{i}$; $\mathrm{P}$ is the average precipitation of the series; $\mathrm{Zi}$, the rainfall estimated by the CMORPH at time $\mathrm{i}$; e $\mathrm{Z}$ is the average precipitation of the CMORPH. This coefficient assumes values between -1 and 1 .

$\mathrm{r}=1$ means a positive perfect correlation between the two variables.

$r=-1$ means a perfect negative correlation between the two variables. This refers, if one increases another always decreases.

$r=0$ means that the two variables do not depend linearly on each other. However, there may be a non-linear dependency. Then, the result $r=0$ must be investigated by other means.

\subsection{Analysis of the day cycle of the Convection}

In order to investigate the daily distribution of rain over RAP, the phase concept will be defined, in order to study the characteristics of the diurnal cycle of austral summer precipitation.

The phase of the diurnal cycle refers to the period of time during which the peaks of precipitation appear. Given that solar radiation is the dominant factor that generates the diurnal cycle of meteorological variables, the rate of precipitation estimates is in Coordinated Universal Time (UTC) and were converted for the local time (LTime), from this time used refers to the LTime.

To have a greater ease of analysis to the data set of the CMORPH, averages were made and accumulated for the austral summer of the period from 2002 to 2014, plotting graphs and analyzing the time of occurrence of the convective events and the peak hours of the extreme values of precipitation in the diurnal cycle.

Seven sub-regions were selected using criteria of similarity in the seasonal rainfall regime to better understand and explain the CDC in the PAR, due to the complexity of the study area which includes islands, mountains, basins, Peruvian altiplano and the lake Titicaca. These seven sub-regions are presented in Figure 6; four of them are in the continent and three in the lake. 
The 1st International Electronic Conference on Hydrological Cycle (CHyCle-2017), 12 - 16 November 2017; Sciforum Electronic Conference Series, Vol. 1, 2017

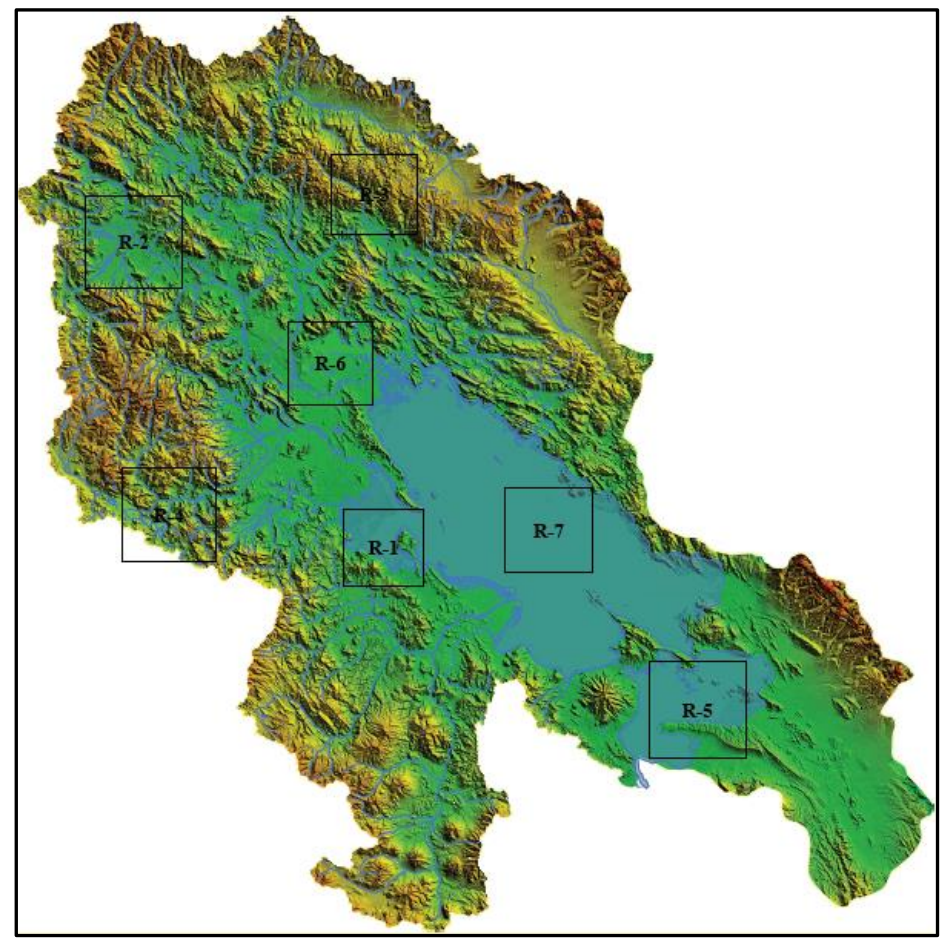

Figure 6. Map of sub-regions. Region 1 (70 $\left.{ }^{\circ} 01^{\prime} 18-69^{\circ} 44^{\prime} 55 \mathrm{~W}, 15^{\circ} 58^{\prime} 28-15^{\circ} 43^{\prime} 13 \mathrm{~S}\right)$; Region 2 (70 ${ }^{\circ}$ $\left.53^{\prime} 20-70 \circ 33^{\prime} 54 \mathrm{~W}, 14^{\circ} 39^{\prime} 35-14^{\circ} 58^{\prime} 15 \mathrm{~S}\right)$; Region 3 (70 $\left.{ }^{\circ} 03^{\prime} 47-69^{\circ} 46^{\prime} 15 \mathrm{~W}, 14^{\circ} 31^{\prime} 12-14^{\circ} 47^{\prime} 35 \mathrm{~S}\right)$; Region 4 (70 $\left.{ }^{\circ} 46^{\prime} 05-70^{\circ} 27^{\prime} 02 \mathrm{~W}, 15^{\circ} 34^{\prime} 51-15^{\circ} 53 ' 31 \mathrm{~S}\right)$; Region 5 (68 ${ }^{\circ} 59^{\prime} 27-68^{\circ} 39^{\prime} 56 \mathrm{~W}, 16^{\circ} 13^{\prime} 59-16$ $\left.{ }^{\circ} 33^{\prime} 32 \mathrm{~S}\right)$; Region 6 (70 $\left.{ }^{\circ} 12^{\prime} 32-69^{\circ} 55^{\prime} 16 \mathrm{~W}, 15^{\circ} 05^{\prime} 02-15^{\circ} 21^{\prime} 56 \mathrm{~S}\right)$; Region 7 (68 ${ }^{\circ} 28^{\prime} 43-69^{\circ} 10^{\prime} 49 \mathrm{~W}, 15$ $\left.\circ 38^{\prime} 39-15^{\circ} 55^{\prime} 485\right)$.

\subsection{ARPS model}

The ARPS (Advanced Regional Prediction System) weather model was created by the CAPS (Center for Analysis and Prediction of Stroms) at the University of Oklahoma. This model is appropriate for the assimilation of meteorological data necessary to the characterization of meteorological systems of interest. According to Xue et al [10,11].

Table 2 shows the set of variáveis that the ARPS model solves explicitly and that are independent of the Cartesian coordinates $(x, y, z, t)$, and together make up the equations of the dynamics of the fluids. Other variables are generated after the post-processing, which are found in table 3 . 
Table 2. Variables explicitly simulated by the ARPS. Vemado [12].

\begin{tabular}{lc}
\hline \multicolumn{1}{c}{ Variable } & Units \\
\hline Potential Temperature ( $\theta$ ) & $\mathrm{K}$ \\
Atmospheric Pressure (p) & $\mathrm{Pa}$ \\
Reason for Mistura do Vapor de agua (qv) & $\mathrm{gkg}^{-1}$ \\
Nuve Water Mistura Ratio (qc) & $\mathrm{gkg}^{-1}$ \\
Reason for Rain Water Mistura (qr) & $\mathrm{gkg}^{-1}$ \\
Reason for Water Mistura in the form of Cristais de Gelo (qi) & $\mathrm{gkg}^{-1}$ \\
Reason for Water Mistura in the Form of Neve (qs) & $\mathrm{gkg}^{-1}$ \\
Reason for Mistura of Water in the Form of Hail (qh) & $\mathrm{gkg}^{-1}$ \\
Turbulent Kinetic Energy (tke) & $\mathrm{m}^{2} \mathrm{~s}^{-2}$ \\
Zonal Component of the Wind (u) & $\mathrm{ms}^{-1}$ \\
Southern Component of the Wind (v) & $\mathrm{ms}^{-1}$ \\
Vertical Component of the Wind (w) & $\mathrm{ms}^{-1}$ \\
\hline
\end{tabular}

Table 3. Variables calculated in the post processing. Vemado [12].

\begin{tabular}{lc}
\hline \multicolumn{1}{c}{ Variable } & Units \\
\hline Delaire temperature (Celsius) & ${ }^{\circ} \mathrm{C}$ \\
Water vapor pressure (e) & $\mathrm{hPa}$ \\
Relative humidity (UR) & $\%$ \\
Dew point temperature (TD) & ${ }^{\circ} \mathrm{C}$ \\
Saturation temperature of NCL $\left(\mathrm{T}^{*}\right)$ & $\mathrm{K}$ \\
Specific humidity (s) & $\mathrm{gkg}^{-1}$ \\
NCL pressure (PNCL) & $\mathrm{M}$ \\
Altitude of the NCL (ZNCL) & $\mathrm{M}$ \\
Convection inhibition energy (ISCED) & $\mathrm{Jkg}^{-1}$ \\
Convective potential energy available (CAPE) & $\mathrm{Jkg}^{-1}$ \\
Pressure at sea level (slp) & $\mathrm{hPa}^{\text {Vertical Component of the Wind (w) }}$ \\
\hline
\end{tabular}

\section{Results}

\subsection{CMORPH - observed values}

- Punctual rainfall assessment

In this stage, the series of precipitation observed in the pluviometer was compared directly with the estimated series of the CMORPH in the respective pixel in which the pluviometer is located, 
The 1st International Electronic Conference on Hydrological Cycle (CHyCle-2017), 12 - 16 November 2017; Sciforum Electronic Conference Series, Vol. 1, 2017

remembering that each pixel has an area of approximately $14 \mathrm{Km}^{2}$ and the rainfall estimates derived from the CMORPH is generated from the average of the entire pixel.

Considering the spatial limitation, the methodology constitutes a preliminary evaluation between the values estimated by the CMORPH and the observed data. For the comparison the 34 pluviometric positions (observed and estimated) were chosen.

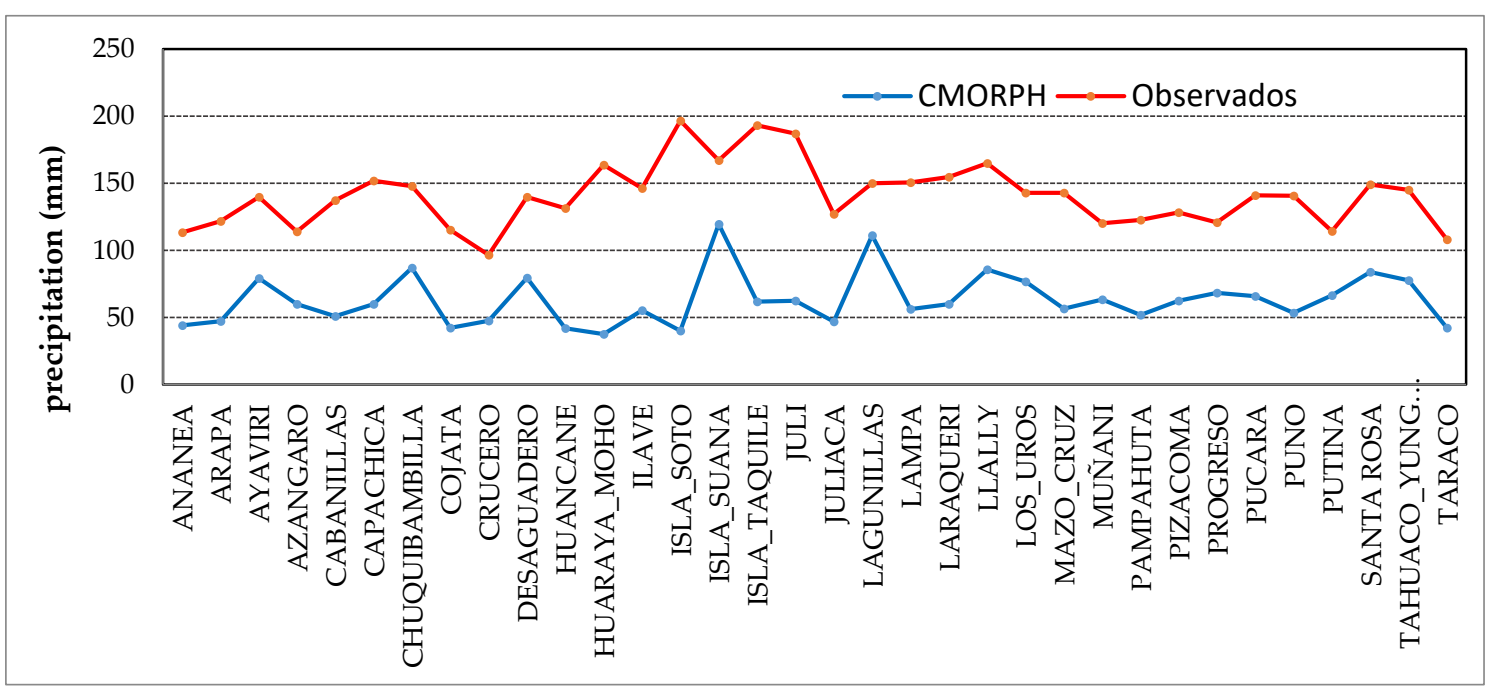

Figure 7. Graph of comparison of the pluviometric data of the 34 stations. Average rainfall for the austral summer (DJF). Red line represents the observed data, blue line represents the estimates of the CMORPH.

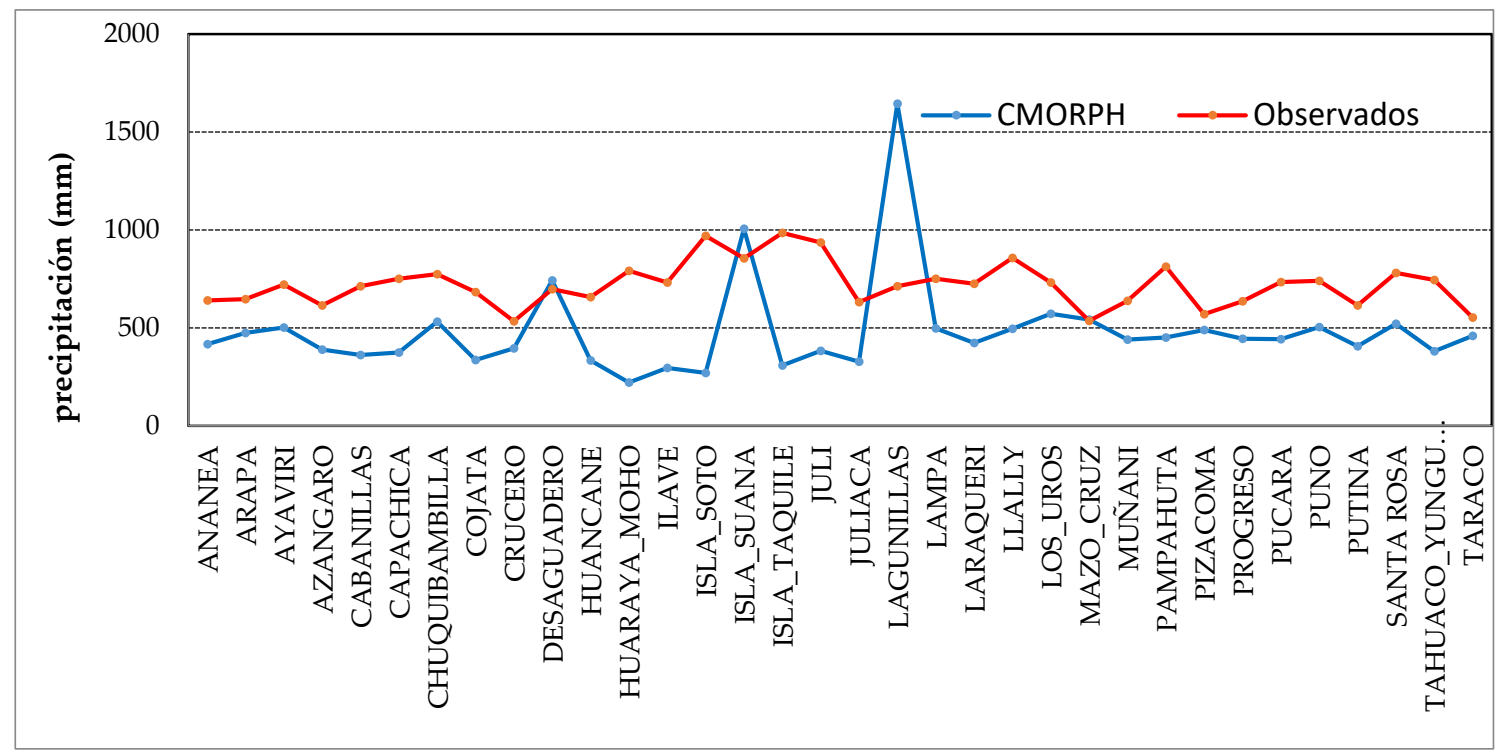

Figure 8. Graph of comparison of rainfall data from 34 stations. Average annual rainfall (period 20022014). Red line represents the observed data, blue line represents the estimates of the CMORPH. Period evaluated: Annual. 


\section{- Evaluation between precipitation fields}

To make a more realistic comparison, the precipitation field estimated by the CMORPH was compared with the field generated from the interpolation of rainfall observed through the methodology of linear multiple regression, where the variable of the topography is included.

\section{- $\quad$ CMORPH qualitative analysis}

Figure 9 (a) and (b) show the spatialization of the average annual precipitation (CMORPH and observed), in general CMROPH managed to represent the spatial distribution of precipitation compared to the map of observed data. The northern region was highlighted by the color similarities of precipitation intensity, probably due to the higher density of pluviometer points. This higher rainfall density makes the observed precipitation surface (generated by the interpolation of rainfall data) more accurate, and therefore there is a greater coincidence with the CMORPH. On the other hand, for the Lake Titicaca region it has very low values for the observed data.

For the austral summer (c) and (d), in general, the spatialization of rain by the CMORPH manages to represent the distribution pattern of the rain, but the values of the CMORPH are below the observed values. Recalling that the highest values of rainfall observed are presented in the Lake Titicaca region and when making a qualitative comparison with the estimates of the CMORPH, it was observed that the highest values of rainfall estimates are found in the center-east and southeast regions.

\section{- CMORPH quantitative analysis}

The index presented in this analysis is the bias, which represents the difference between the precipitation estimates and the observed precipitation. In general, CMORPH presented a high percentage of underestimation for the annual cycle ( $300 \%$ on average), and ( $78 \%$ on average) for the austral summer.

Estimates of precipitation from CMORPH, a method that uses a much wider range of information sources, were able to estimate on average only $43 \%$ of the total volumes of rainfall for the austral summer and an average of $58 \%$ for the period annual. 
The 1st International Electronic Conference on Hydrological Cycle (CHyCle-2017), 12 - 16 November 2017; Sciforum Electronic Conference Series, Vol. 1, 2017
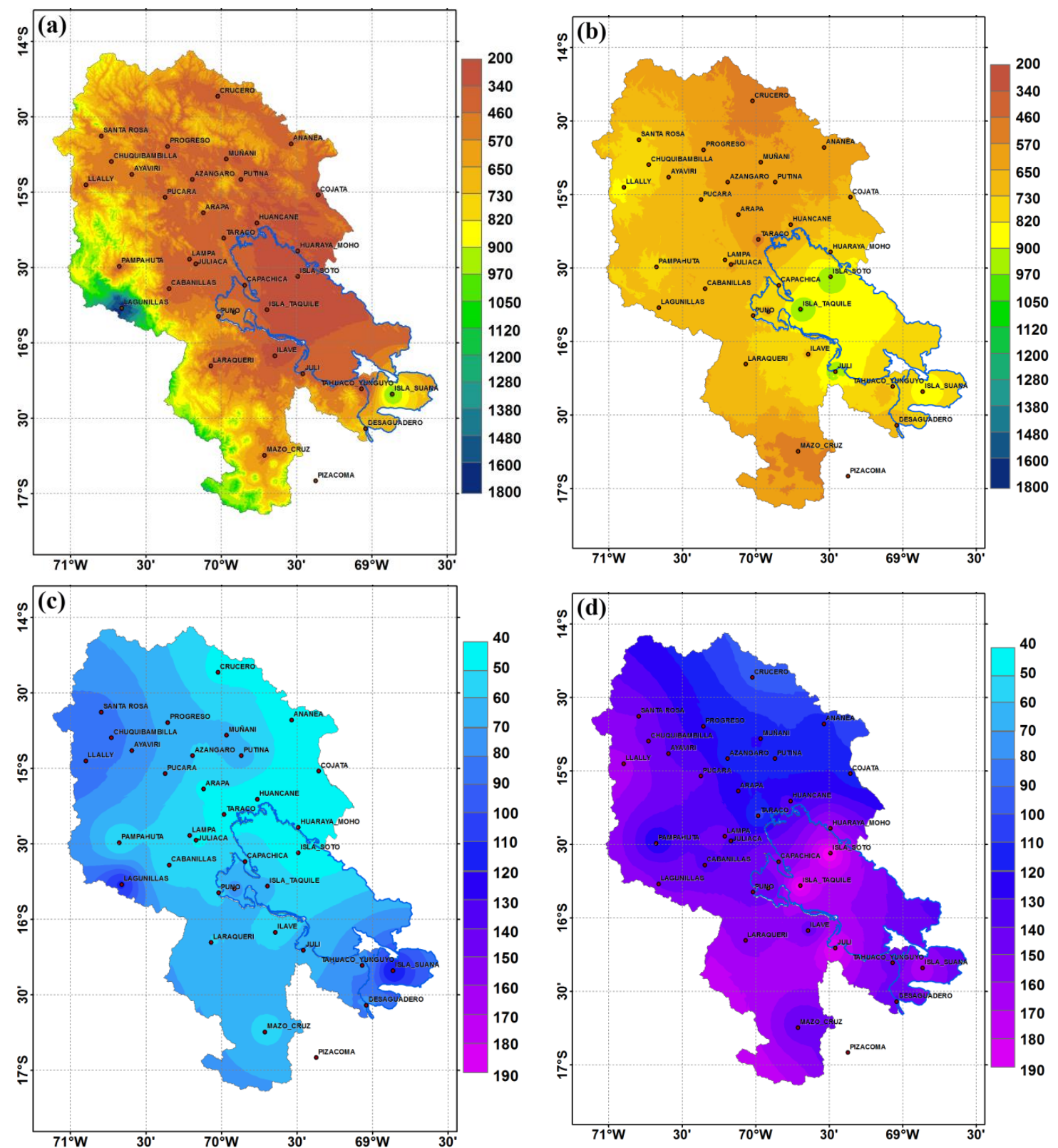

Figure 9. Map of annual distribution of average annual rainfall: (a) $\mathrm{CMORPH}$, (b) observed data. For the austral summer (DJF): (c) CMORPH, (d) observed data. The scale in colors represents the precipitation in millimeters (mm). Period 2002-2014. Vertical axis indicates the latitudes and the horizontal axis refers to the lengths, both em degrees $\left({ }^{\circ}\right)$. 
The 1st International Electronic Conference on Hydrological Cycle (CHyCle-2017), 12 - 16 November 2017; Sciforum Electronic Conference Series, Vol. 1, 2017

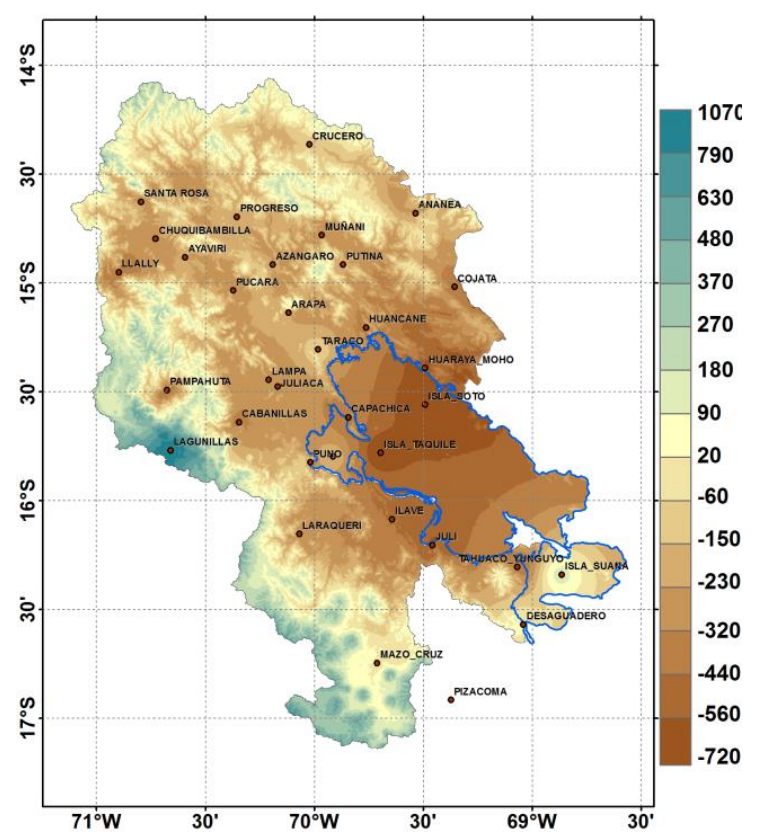

(a)

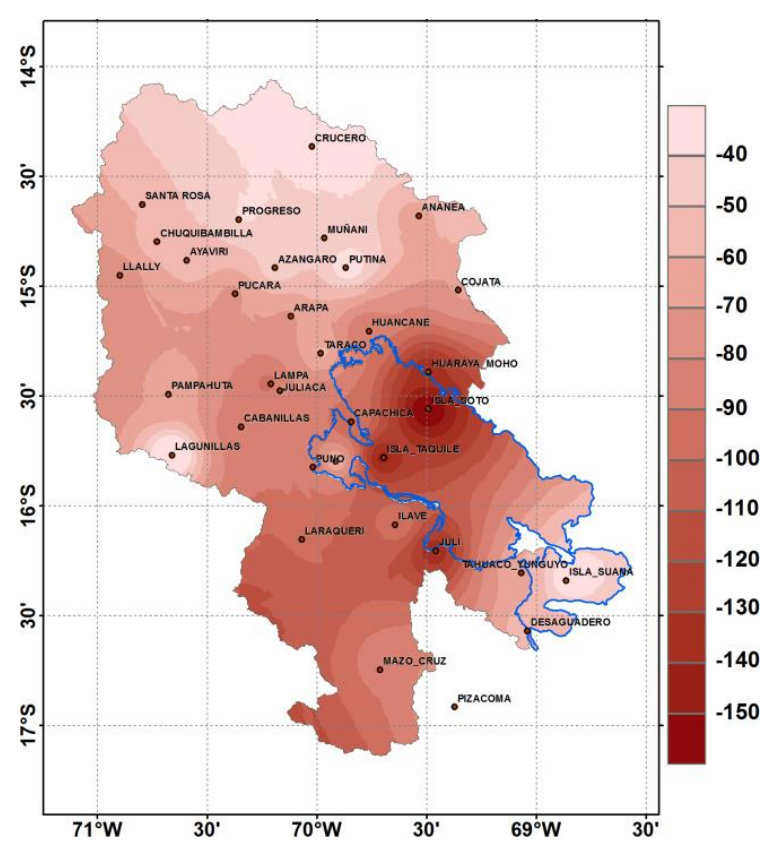

(b)

Figure 10. Bias spatialization map for the annual precipitation cycle (a), and for the austral summer (b). Period 2002-2014. Scale in colors represents the underestimation or overestimation of the precipitation estimate compared to the observed data.

Figure 10 (a) shows the spatial distribution of the bias calculation for the annual average precipitation, the southeast region, the center-east and the north present values of underestimation and the highest values are concentrated in the center-west region with a percentage of $700 \%$ on average. Super-values are located in the central-western and southeastern regions, representing $12 \%$ of the rainfall points analyzed in the Peruvian Altiplano region.

Table 4 presents the values of the correlation coefficients for the austral summer (2002-2014), where, coincidentally, of the 34 pluviometric points 50\% (17) has a linearly positive dependence and the other $50 \%$ presented a dependence linearly negative.

Table 4. Correlations between CMORPH values and Observed data

\begin{tabular}{llllllll}
\hline Ananea & $-0,27$ & Desaguadero & 0,04 & Lagunillas & $-0,48$ & Progreso & $-0,10$ \\
Arapa & $-0,27$ & Huancane & $-0,19$ & Lampa & $-0,07$ & Pucara & $-0,14$ \\
Ayaviri & $-0,04$ & Huaraya & 0,51 & Laraqueri & 0,41 & Puno & 0,12 \\
Azangaro & $-0,21$ & Ilave & 0,53 & Llally & 0,38 & Putina & $-0,42$ \\
Cabanillas & 0,08 & Isla Soto & 0,64 & Los Uros & 0,37 & Santa Ros a & 0,46 \\
Capachica & 0,11 & Isla Suana & 0,81 & Mazo Cruz & $-0,25$ & Tahuaco & 0,66 \\
Chuquibambilla & $-0,09$ & Isla Taquile & 0,55 & Munani & $-0,35$ & Taraco & $-0,04$ \\
Collata & 0,52 & Juli & 0,54 & Pampahuata & $-0,29$ & & \\
Crucero & 0,57 & Juliaca & $-0,01$ & Pizacona & $-0,41$ & & \\
\hline
\end{tabular}




\subsection{Precipitation climatology}

The results show a non-uniform distribution of rainfall estimates over the region of our interest (Figure 10), this is due to the presence of the Andes mountain range, which has a greater influence on rainfall patterns in the RAP. The maximum precipitation has a presence on the north and east outside the TL basin (green, yellow and orange colors), which is generated by the presence of the mountain chain which acts as a natural barrier, restricting the entry of moisture from of the Amazon.

The CMORPH manages to identify the Foehn effect, remembering that the topography forces the ascending air mass, condensing the water vapor and giving rise to orographic rains. To the leeward, the dry air rapidly decreases, increasing atmospheric pressure and temperature (Foehn effect), due to the high spatial resolution. Humid air from the Amazon generates generation on the side of the barlavento which causes insufficient supply of water vapor on the leeward side.

These results were also obtained by Xin-Xin [13], who used satellite data from CMORPH and TRMM on the South and East Asia region.

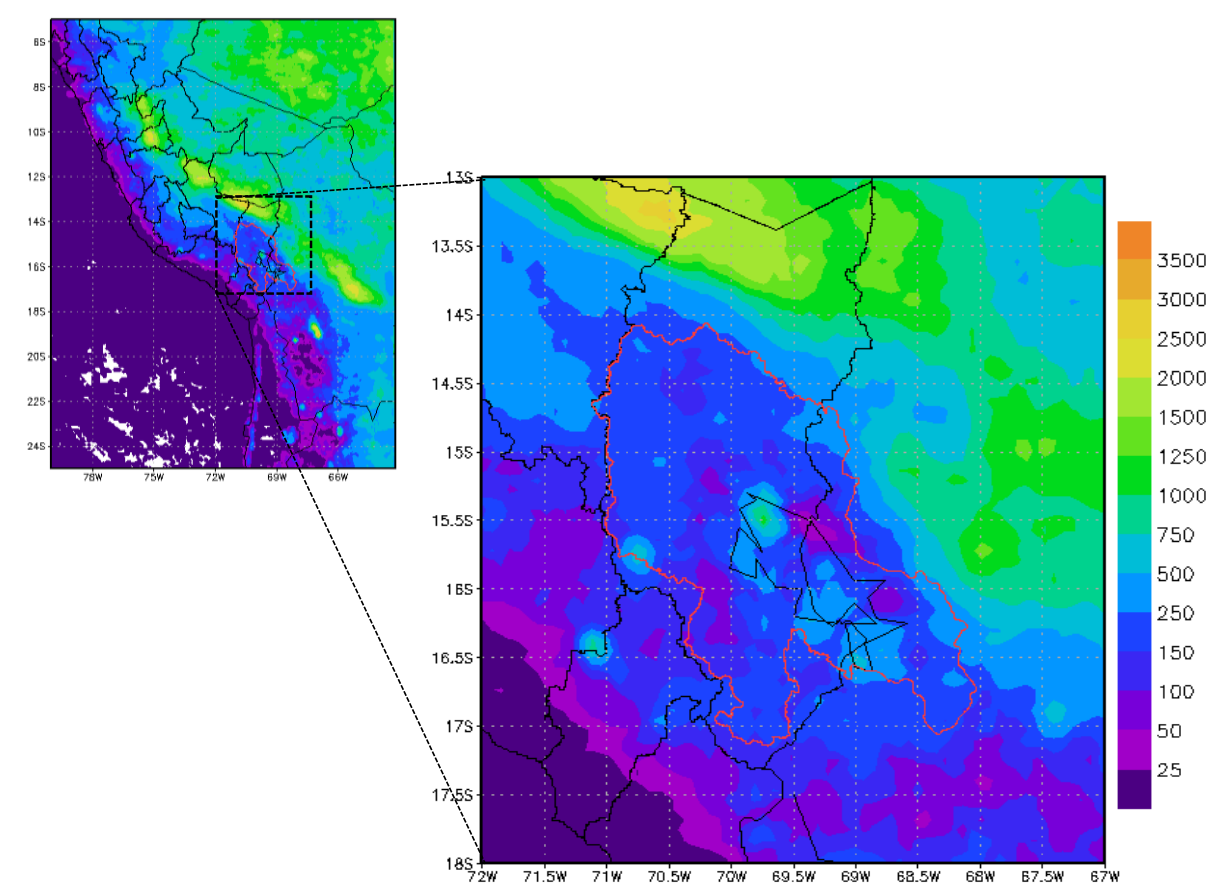

Figure 11. Distribution of the average rate of precipitation estimates (units: $\mathrm{mm}$ ) for the austral summer period 2002-2014, derived from the Climate Prediction Center (CPC) MORPHing Technique (CMORPH). Vertical axis indicates the latitudes and the horizontal axis refers to the lengths, both in degrees $\left({ }^{\circ}\right)$. The red color represents the Lake Titicaca River Basin.

\subsection{Diurnal cycle of convection using data from $\mathrm{CMORPH}$}

Many studies have demonstrated the reliability of TRMM to analyze the diurnal cycle of precipitation compared to the observed data [14, 15, 16, 17]. But considering its limitations of thick resolution of the TRMM, the use of the CMORPH with high resolution, temporary space, shows a better spatial and temporal distribution of rainfall estimates during the CDC for the austral summer (DJF). 
The 1st International Electronic Conference on Hydrological Cycle (CHyCle-2017), 12 - 16 November 2017; Sciforum Electronic Conference Series, Vol. 1, 2017

Figure 12 shows the scheludes and zones where the precipitations occurred. During the early morning period the occurrence of rains is on the TL in the hour from 2: 00h until 6: 00h, where the maximum values for that period of precipitation occur at 3: $00 \mathrm{~h}$ and $4: 00 \mathrm{~h}$ in the region north of the TL.

The circulation of the end of the night, with the air coming from the continent to the lake, genera a front of terrestrial breeze with upward movement on the lake. In some cases it is possible to observe the formation of clouds and cores of precipitation estimates. In the analyzed figures it is possible to observe the presence of seasonal convective systems of smaller extensions over the TL region. Both the northern and southern part of the convective events highlight the northern zone as the region where the most important values of rainfall estimates are presented.

To the northeast of the TL basin you can see the presence of convective systems restricted by the Andes mountain range. It is clear to observe the effect of the CA where it develops the maximums of the precipitation well located along the east slope of the same on the west of Bolívia.

In Figure 12, you can see the formation and development of convective systems around the TL in the afternoon period, which is related to the local circulation of lake breeze from the lake to the continent. At 1:00 pm, it is possible to observe the formation of clouds on the continent. With the displacement of the breeze front within the continent, the propagation of a nebulosity band is observed, easily verifiable in the images generated with the CMORPH data (1:00 p.m. and 2:00 p.m.). This type of circulation is the most active during the period of the day because it increases the solar heating and also the pressure gradient, which generates the most intense winds on the surface that helps the sea breeze reaches its maximum value.

Due to the presence of the mountains, the sea breeze is forced to the ascent and the humidity contained in it to achieve clouds of great vertical development. The first convective systems occurred due to the forcing of the valley-montanha circulation and the occurrence at solar noon or in the first hours of the afternoon (13: $00 \mathrm{~h}$ and 14:00h, our case), when the radioactive heating is maximum. Similar results were obtained by $[18,19,20,21]$. 
The 1st International Electronic Conference on Hydrological Cycle (CHyCle-2017), 12 - 16 November 2017; Sciforum Electronic Conference Series, Vol. 1, 2017
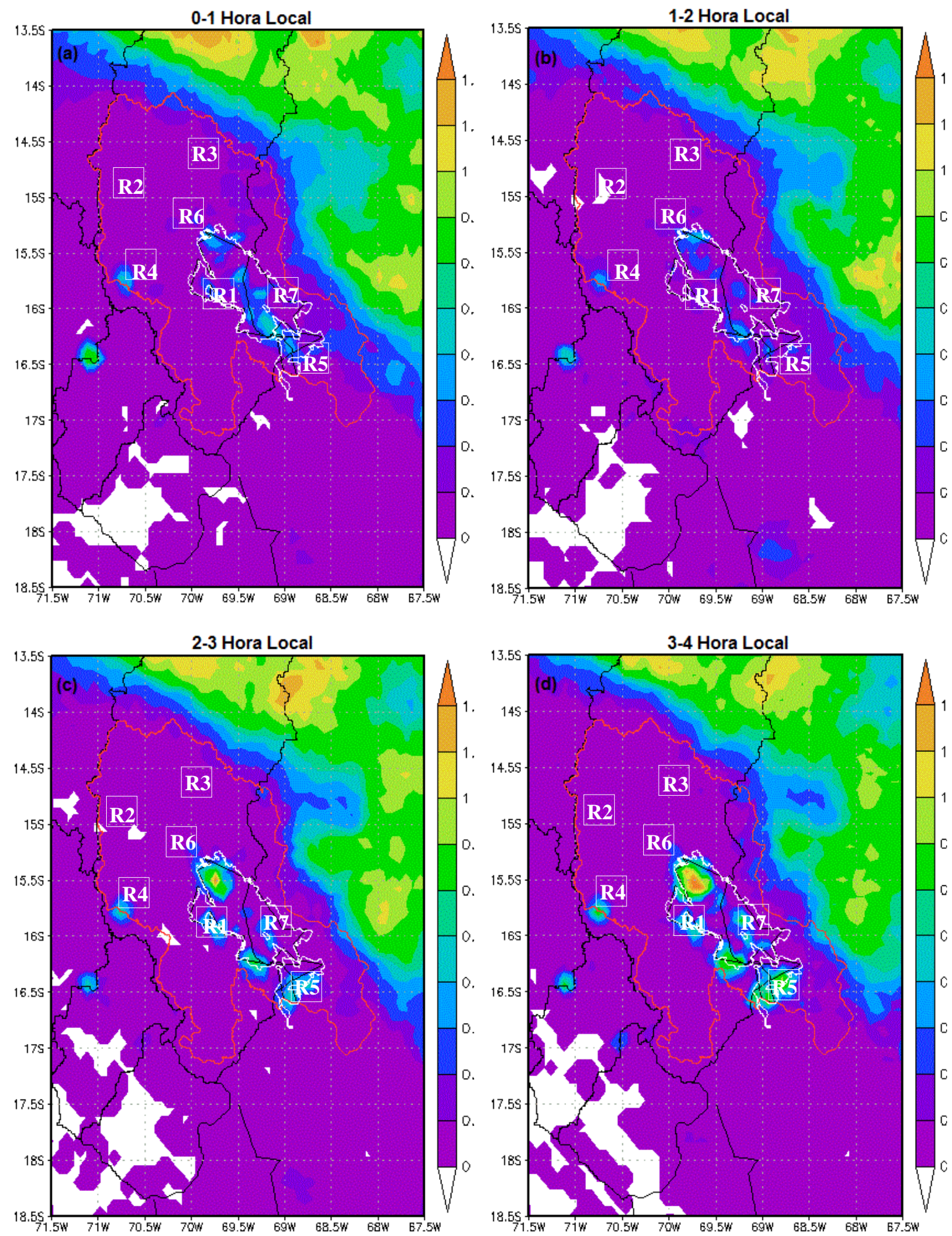

Figure 12. Spatial distribution of the precipitation estimates obtained from the CMORHP data for the austral summer, period 2000-2014. Scale in colires represents precipitation in millimeters (mm / hour). The diurnal cycle of convection is represented in local time. Vertical axis indicates the latitudes and the horizontal axis refers to the lengths, both in degrees $\left(^{\circ}\right)$. The white squares are the regions selected for the analysis. 
The 1st International Electronic Conference on Hydrological Cycle (CHyCle-2017), 12 - 16 November 2017; Sciforum Electronic Conference Series, Vol. 1, 2017
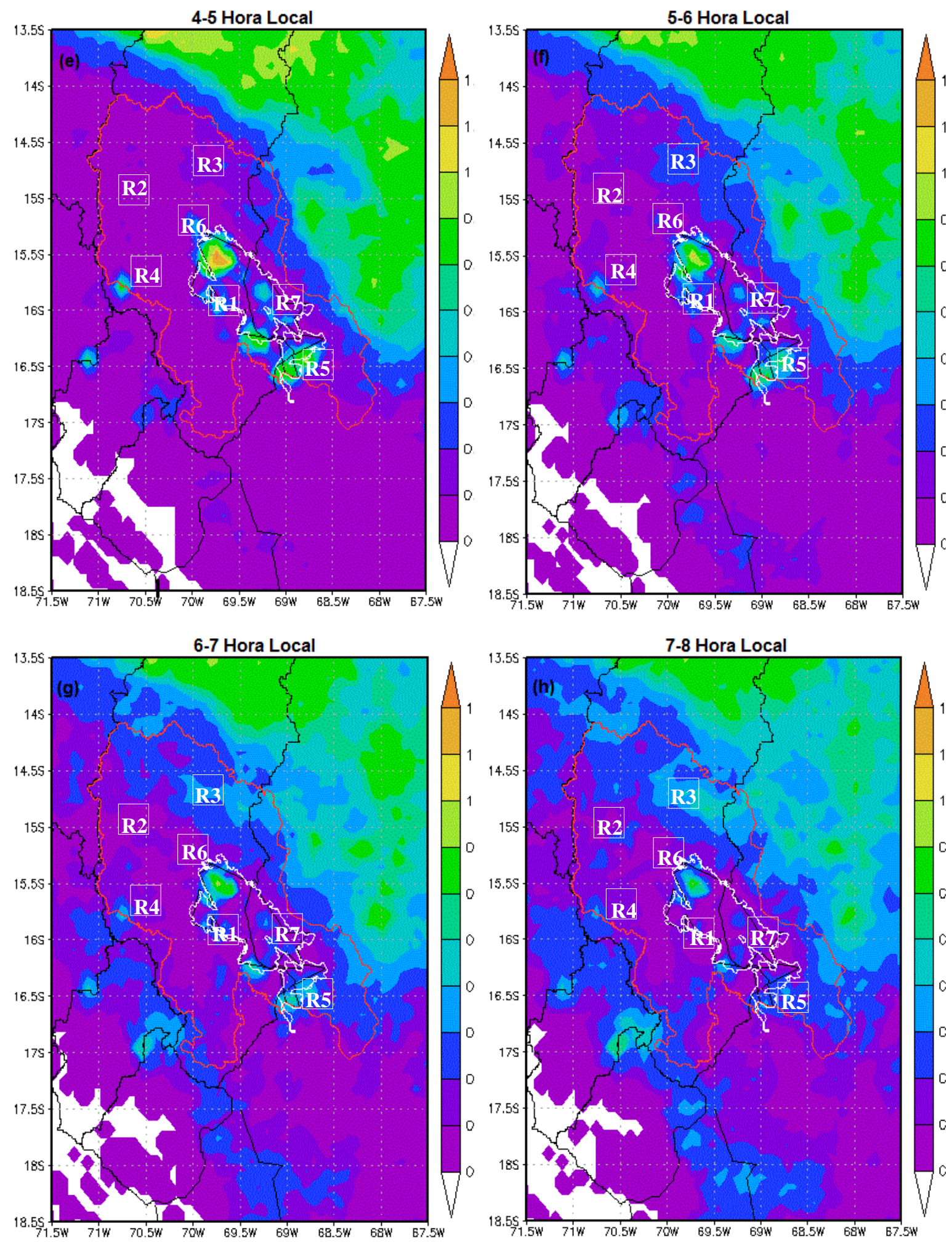

Figure 12 Continuation 
The 1st International Electronic Conference on Hydrological Cycle (CHyCle-2017), 12 - 16 November 2017; Sciforum Electronic Conference Series, Vol. 1, 2017
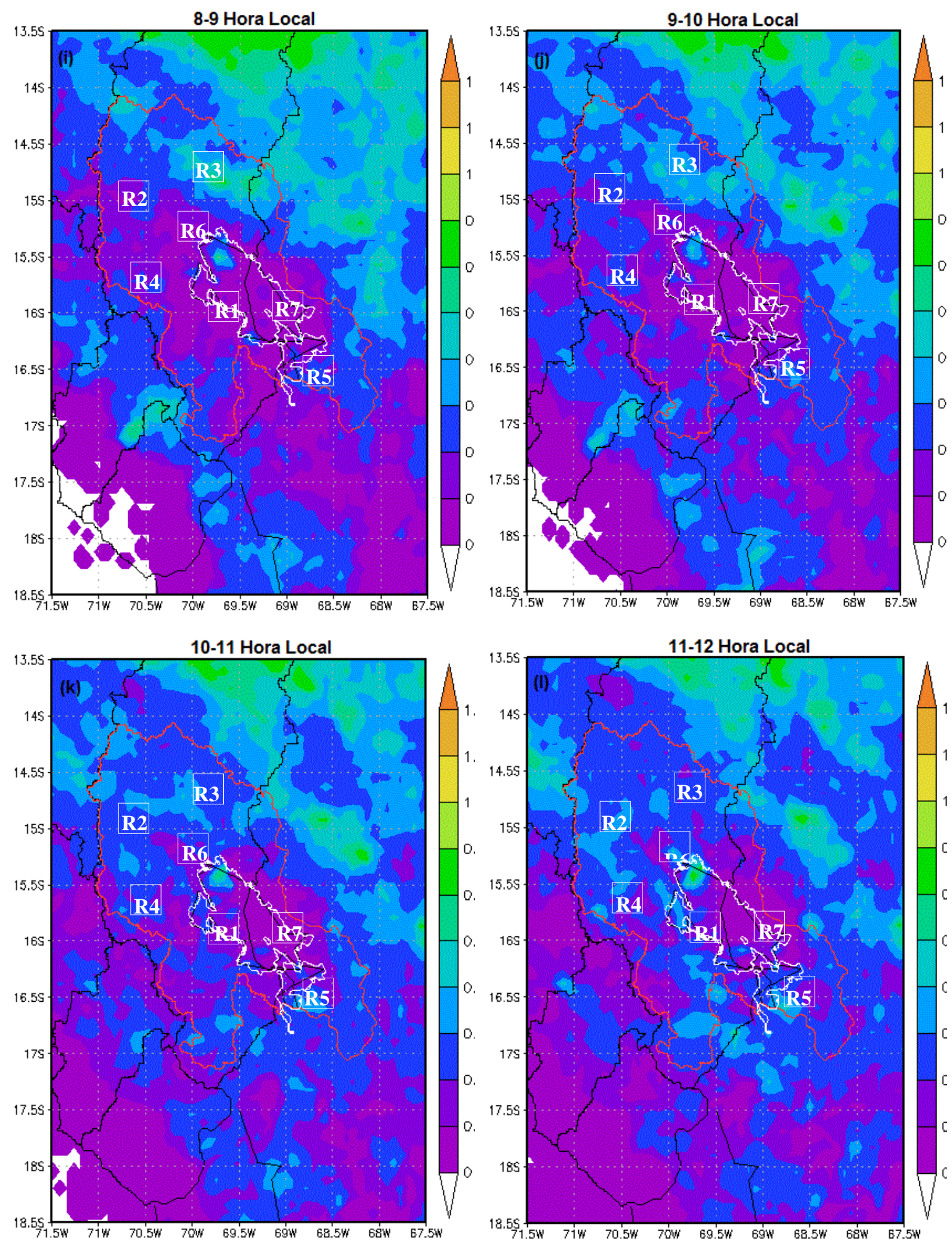

Figure 12 Continuation 
The 1st International Electronic Conference on Hydrological Cycle (CHyCle-2017), 12 - 16 November 2017; Sciforum Electronic Conference Series, Vol. 1, 2017
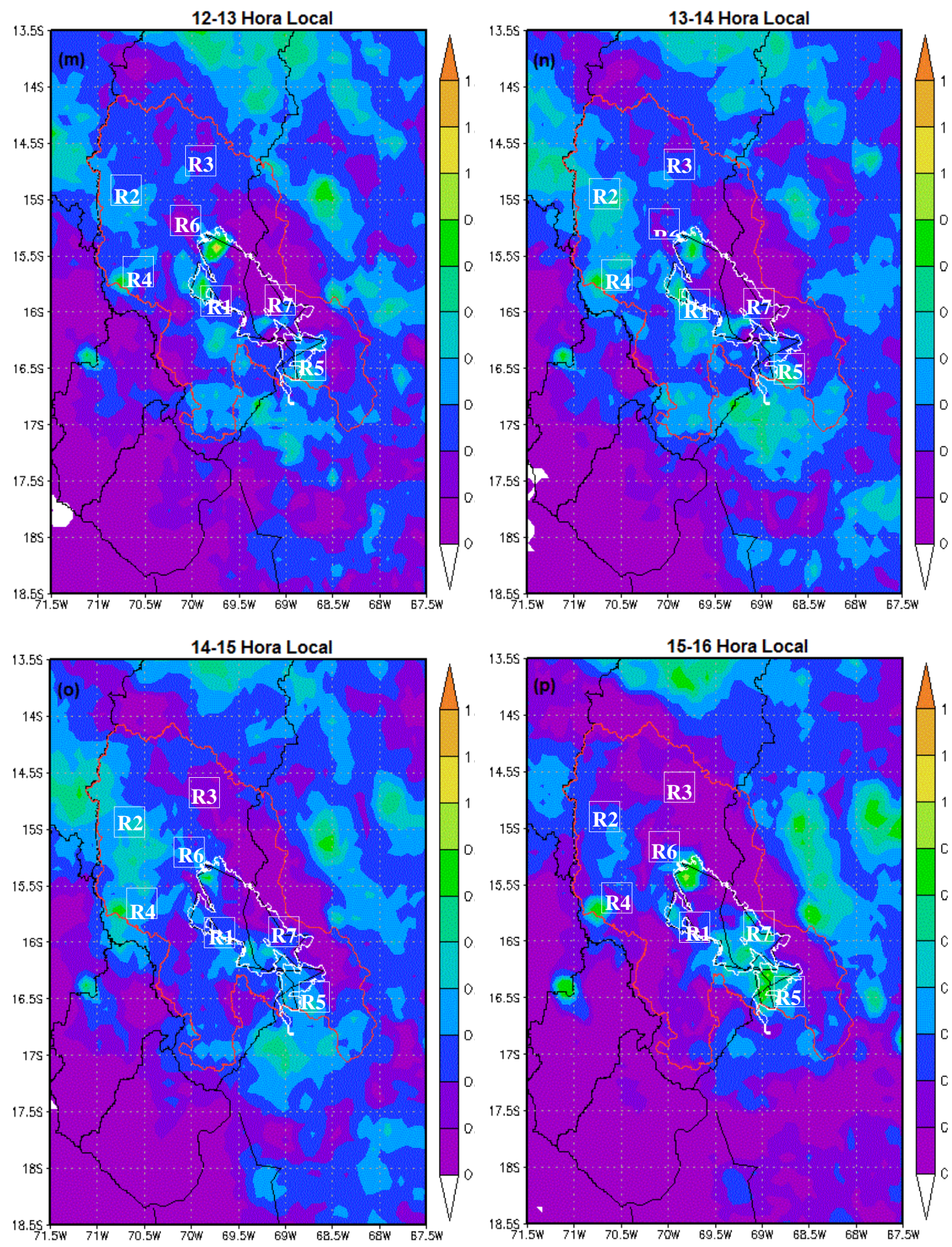

Figure 12 Continuation 
The 1st International Electronic Conference on Hydrological Cycle (CHyCle-2017), 12 - 16 November 2017; Sciforum Electronic Conference Series, Vol. 1, 2017
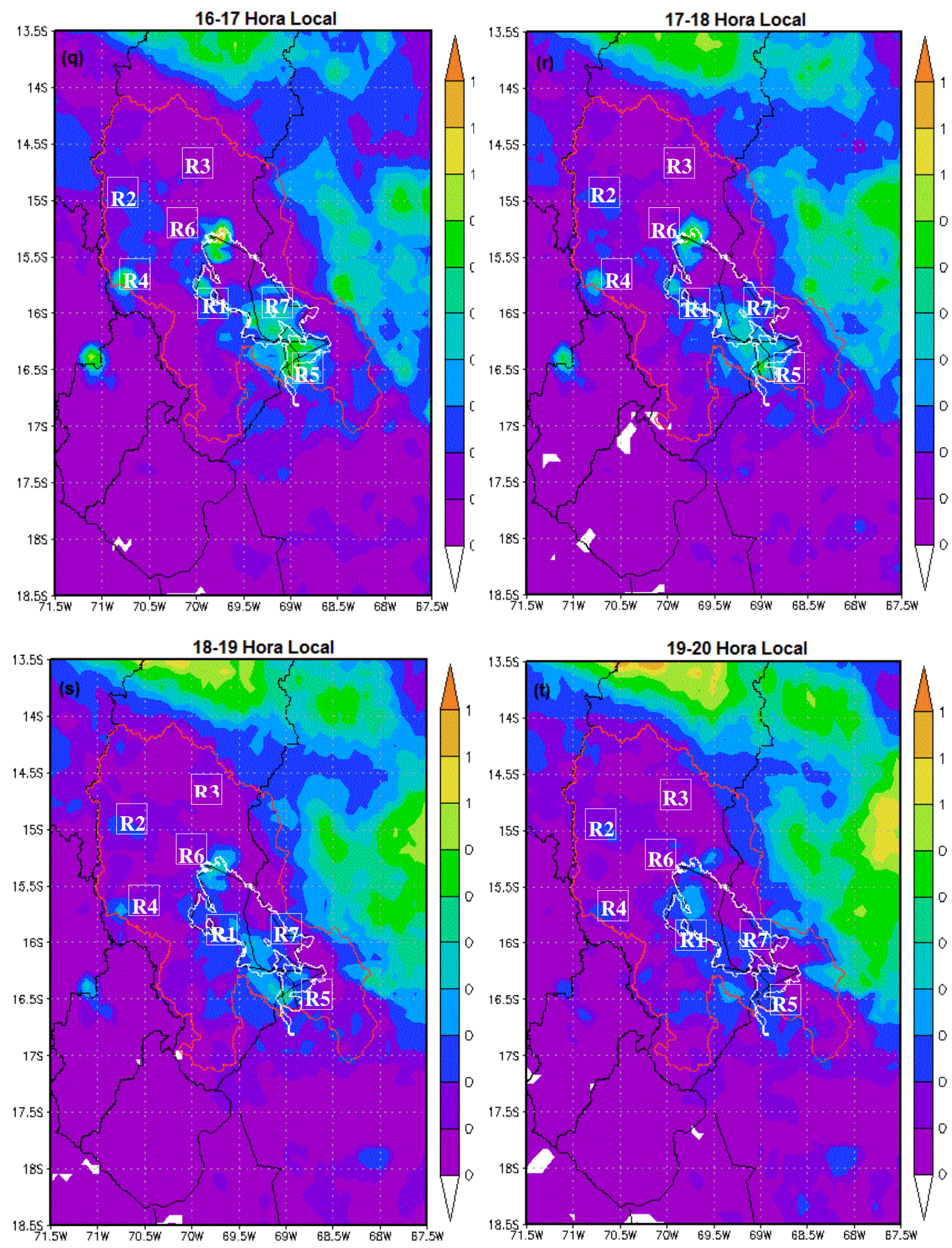

Figure 12 Continuation 
The 1st International Electronic Conference on Hydrological Cycle (CHyCle-2017), 12 - 16 November 2017; Sciforum Electronic Conference Series, Vol. 1, 2017
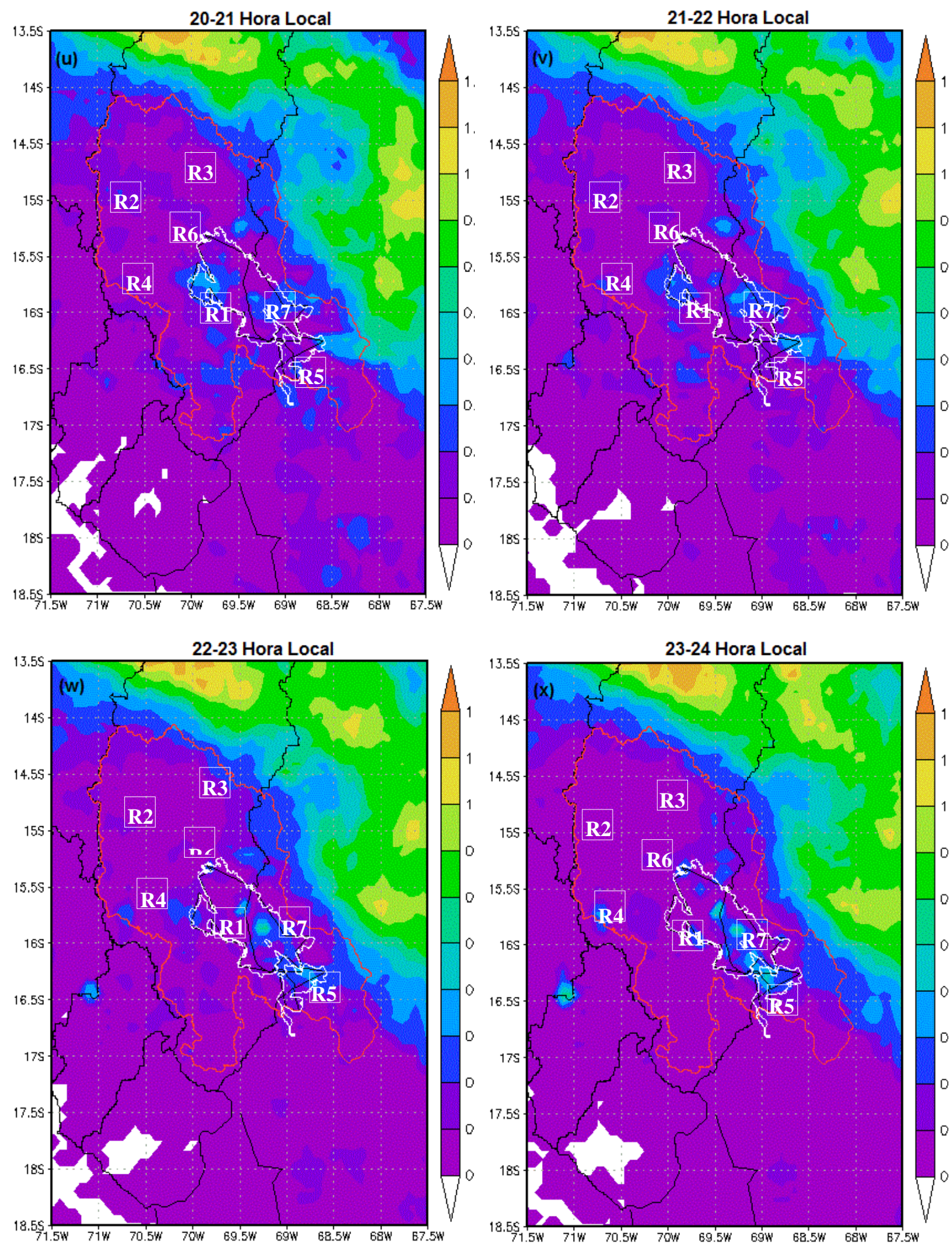

Figure 12 Continuation 
The regional characteristics of the CDC during the austral summer were analyzed, in that sense seven relatively typical sub-regions based on the rainfall behavior were selected.

In Figure 4.11: Region 1 - Puno; Region 2 - Chuquibambilla; Region 3 - Munani; Region 4 Lagunillas; Region 5 - Suana Island; Region 6 - Taraco; and Region 7 - Taquile Island. This criterion shows better the regional difference of the diurnal cycle of convection in regions 4,5 and 6 we have the presence of the semi-diurnal cycle with well determined period of 7 to 9 hours.

For the other regions, the diurnal cycle is dominant and the maximum peaks of precipitation estimates are consistent with the results shown by Xin-xin et al [13].
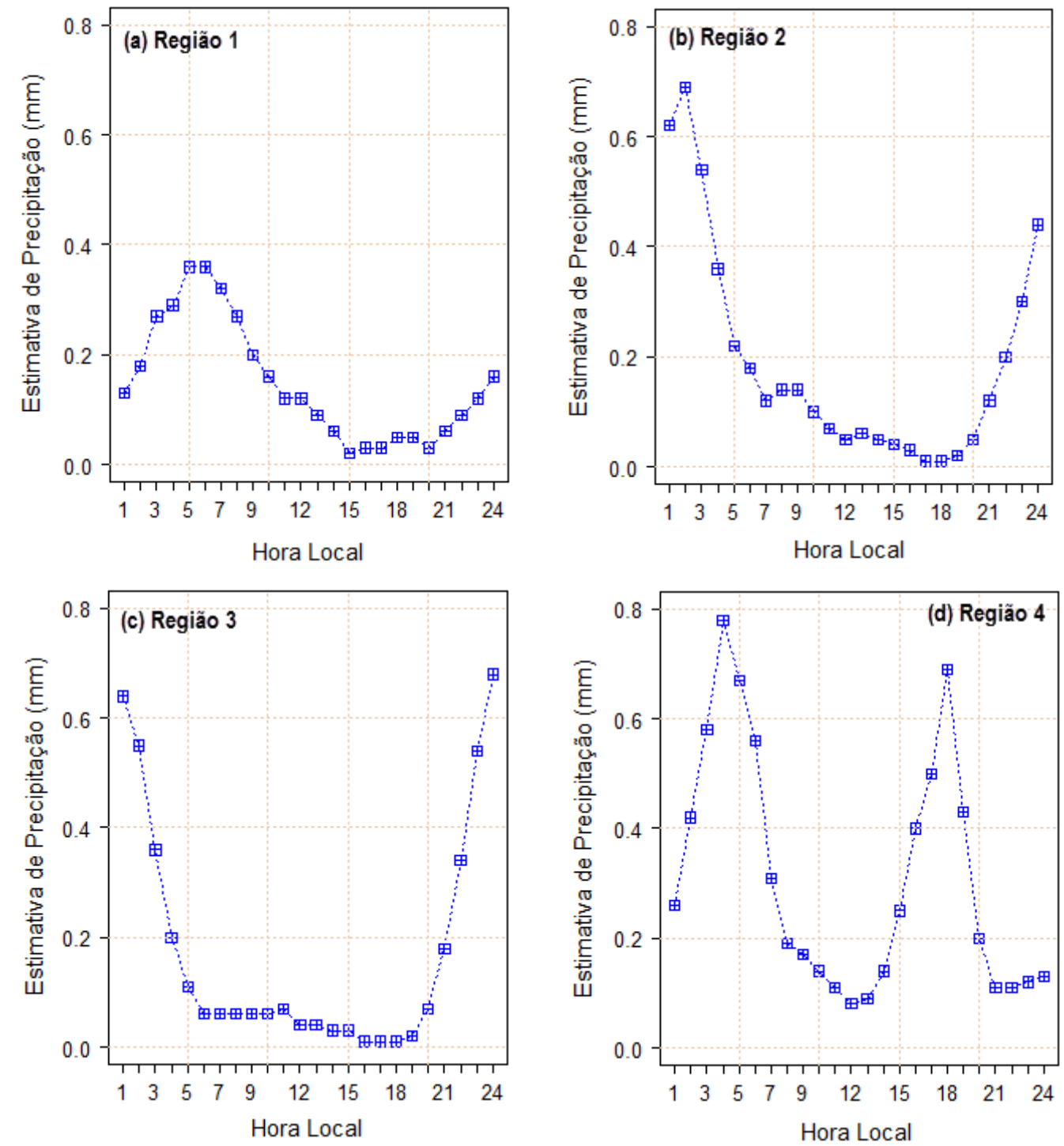

Figure 13. Daytime variation of summer precipitation over the seven regions. The $x-$ axis represents the phase of the diurnal cycle in local time and the y-axis represents average precipitation estimate in millimeters $(\mathrm{mm})$ 
The 1st International Electronic Conference on Hydrological Cycle (CHyCle-2017), 12 - 16 November 2017; Sciforum Electronic Conference Series, Vol. 1, 2017
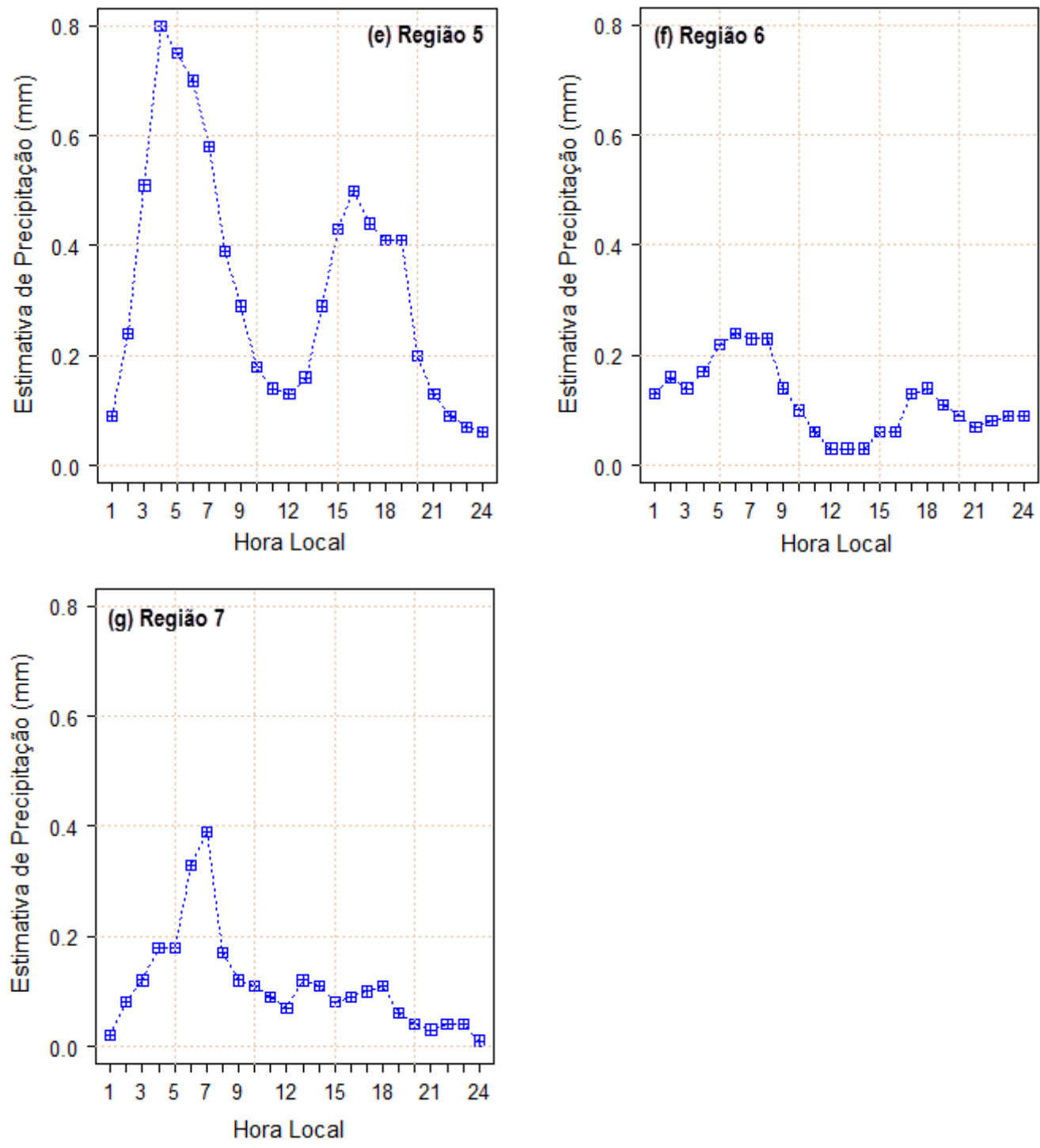

Figure 13 continuation

\subsection{Case studies}

Three convective events were analyzed, from which the case of January 15 - 19, 2014 is presented, the rest is included in the appendix, this convective event was associated with high accumulation of rainwater in the soil, which originated landslide and blockade of access to the municipality of PharaSandia. Available at: http: //www.radiolibertad.con .pe / landslides-and-rains-affect-to-the-provinceof-puno /. Access on 05/21/2014.

The use of the outputs of the ARPS model was used in order to understand the patterns of local circulation that are involved within the CDC.

Figure 14 shows the map of the Lake Titicaca River Basin and the location of the cut line used to analyze the ARPS exits in the selected events. 


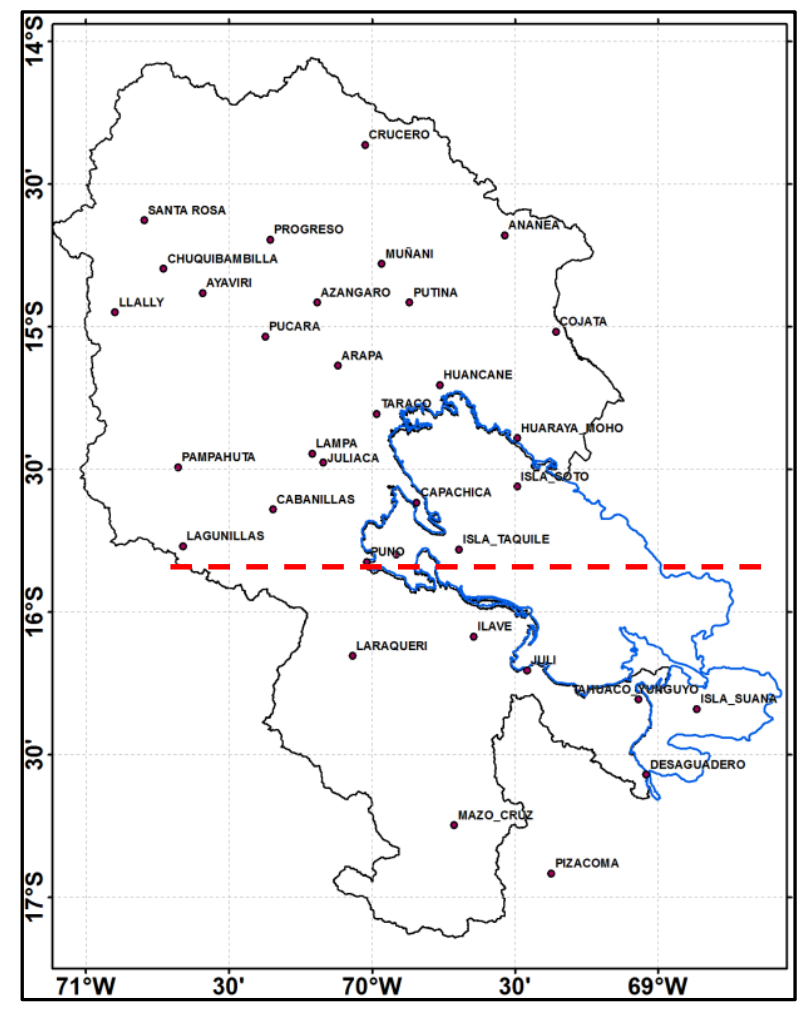

Figure 14. Location map of the cutting line

In figure 15, it shows the complete period of the diurnal cycle simulated by the ARPS. The vertical cut of relative humidity and vertical velocity shows that in the early morning period the humidity is above the TL, and due to night cooling, the earth - water interface begins to act according to forced thermal circulations bringing air from the continent for the TL, the terrestrial breeze front, with upward movement on the TL can develop and generate convective events noturnos.

At the beginning of the morning, due to the heating of the slopes with orientation to the east, the winds cross the Andes montains in the west direction. The air located on the slopes of the western mountain range increases its temperature and begins to rise causing anabatic winds to the top of the elevations, this type of movement creates compensation subsidence on the TL, besides them, the presence of winds is easily observable Kabbats remaining from the previous night which persists until 09: 00h, this is because the hillside is not illuminated in the early hours of the day.

From 10: 00h you can see the coupling of the lacustrine and valley breeze circulation, with the advance of the hours the intensification of this type of local circulation increases the potential of formation of clouds and convective rains in high altitude places of the Western montains.

Convective events begin around 1:00 pm with a duration of approximately 5 to 6 hours. The convective system formed by this type of coupling is managed to move in the direction east getting to reach its maximum development at the edge of the TL. After reaching the maximum values, the winds decrease at the end of the afternoon and the beginning of the night with the solar decrease.

The remaining moisture is transported to the TL by local mountain circulation and land circulation. This type of flow coming from the continent to the Lake causes convective rains in the early morning hours. The maximum value of convection occurs in the middle of the Lake at 05: 00h. 
The 1st International Electronic Conference on Hydrological Cycle (CHyCle-2017), 12 - 16 November 2017; Sciforum Electronic Conference Series, Vol. 1, 2017
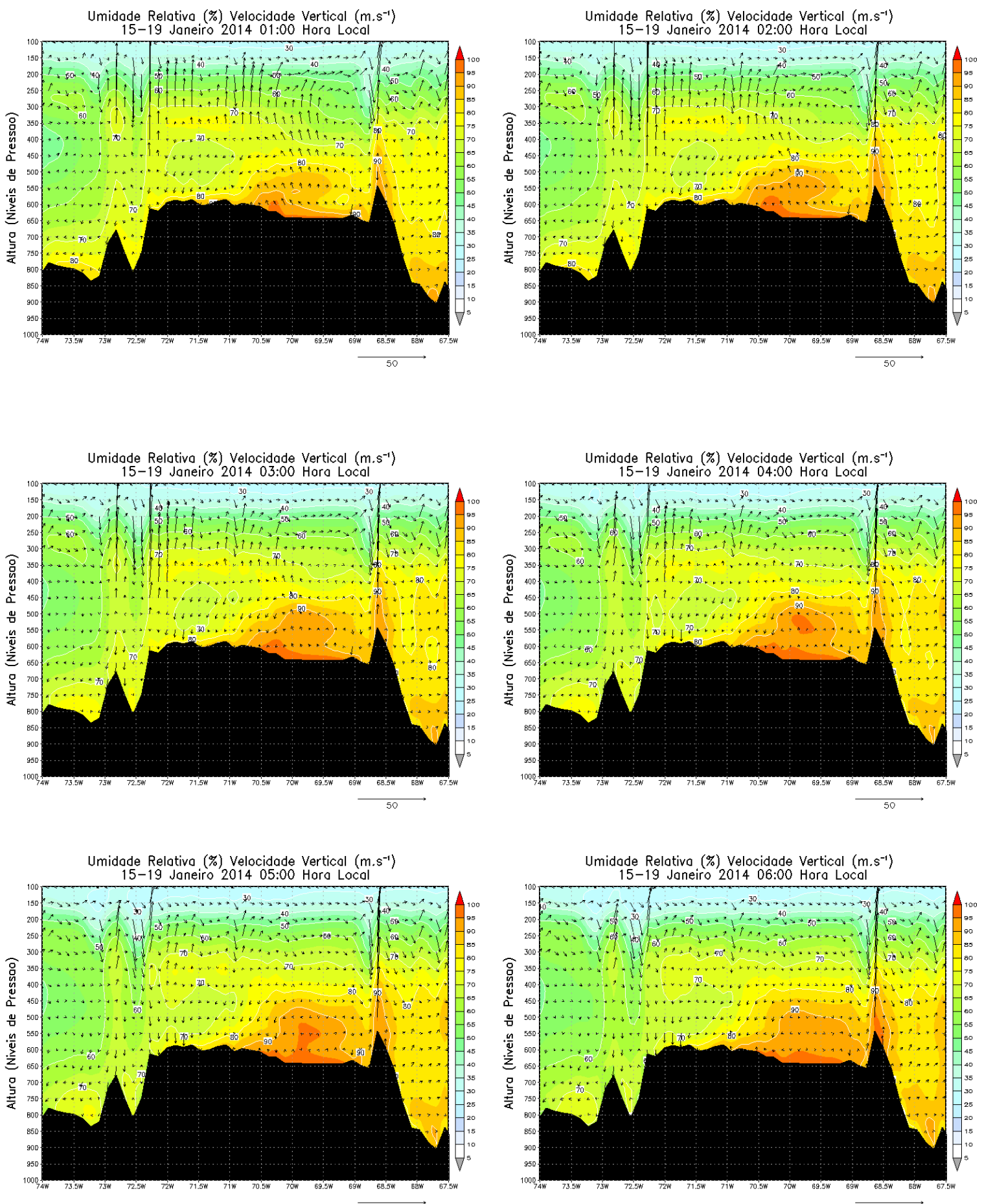

Figure 15. Vertical section of relative humidity (\%) and vertical velocity field (m.s-1). The color bar indicates relative humidity. Horizontal axis refers to the lengths, both in degrees $\left(^{\circ}\right)$. 
The 1st International Electronic Conference on Hydrological Cycle (CHyCle-2017), 12 - 16 November 2017; Sciforum Electronic Conference Series, Vol. 1, 2017
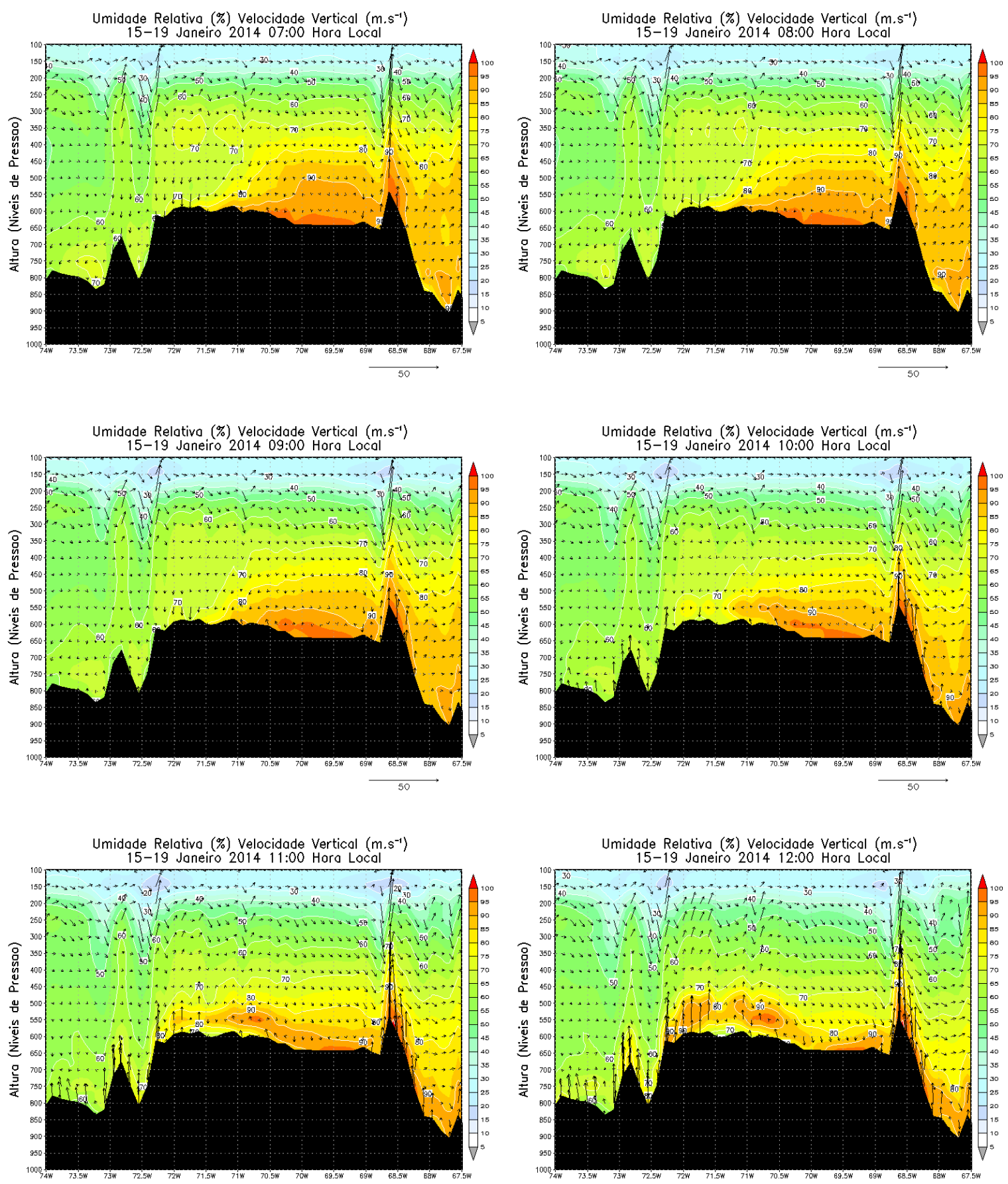

Figure 15 continuation 
The 1st International Electronic Conference on Hydrological Cycle (CHyCle-2017), 12 - 16 November 2017; Sciforum Electronic Conference Series, Vol. 1, 2017
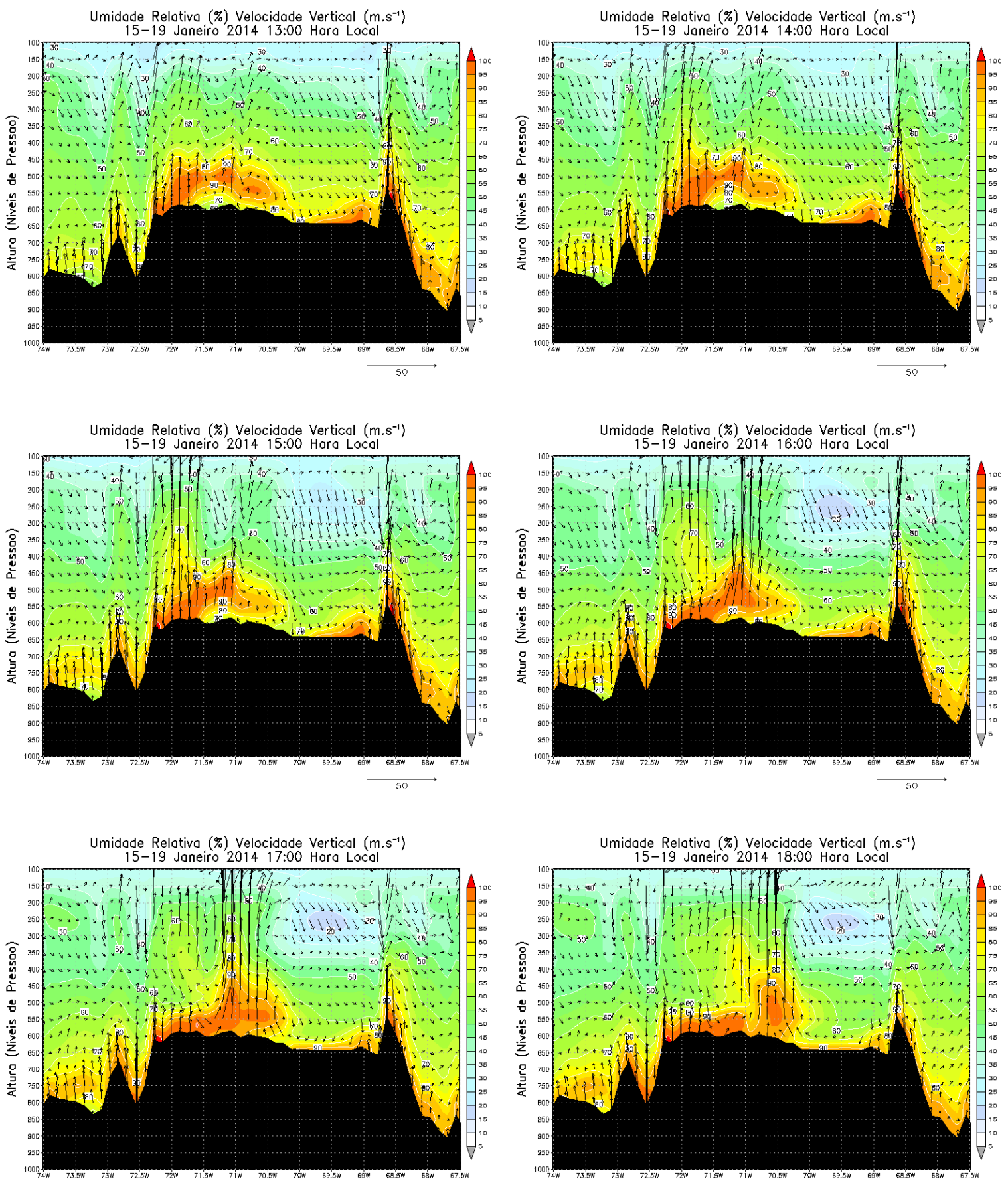

Figure 15 continuation 
The 1st International Electronic Conference on Hydrological Cycle (CHyCle-2017), 12 - 16 November 2017; Sciforum Electronic Conference Series, Vol. 1, 2017
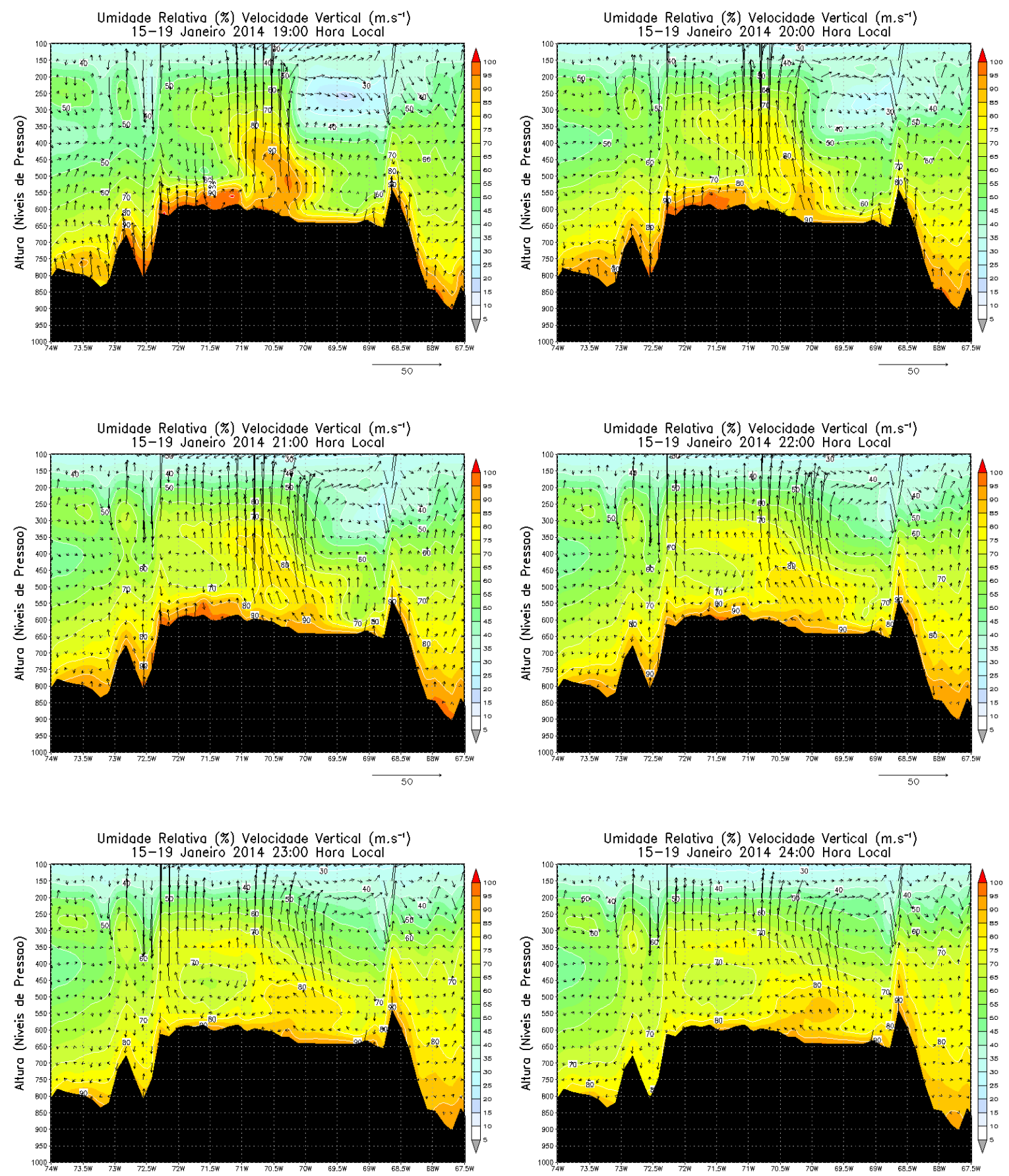

Figure 15 continuation 
The 1st International Electronic Conference on Hydrological Cycle (CHyCle-2017), 12 - 16 November 2017; Sciforum Electronic Conference Series, Vol. 1, 2017

\section{Conclusions}

The estimated annual average precipitation, for the selected period, was $481.8 \mathrm{~mm}$ representing $33 \%$ less than the observed value $(719.5 \mathrm{~mm})$, the value of the Pearson correlation for the average monthly precipitation was 0.89 , thus, it is observed a high relation between the observed value and CMORPH. For a better understanding, pluviometrically homogenous regions were obtained by means of climatological analysis.

The results indicate that the CDC presents high variability in the Titicaca watershed and is associated with lake (day), terrestrial (night) and valley - mountain breeze circulation patterns. The CDC starts at 0200 LT (local time) in the northern region of Lake Titicaca, lasting from $2 \mathrm{~h}$ to $6 \mathrm{~h}$, and maximum at $0600 \mathrm{LT}$. in the terrestrial surface (ST) of the Lake the CDC starts earlier around the 1200 $\mathrm{HL}$, with duration from $4 \mathrm{~h}$ to $7 \mathrm{~h}$, and maximum at $1800 \mathrm{LT}$.

The rainy weather patterns in both the continent and the lake were explained better by the outputs of the ARPS model, where it is clear to see that the convective events are influenced by local circulations (terrestrial-lake breeze and valley-mountain breeze). Similar results were obtained by Xin-xin [13].

In the analysis of the event from January 11 to 15, 2014 it was observed that the greatest source of humidity is Lake Titicaca and local circulation valley - mountain generated in the western mountain range of moisture in smaller quantities which helps in the formation and development of convective systems in the beginning of the afternoon.

Acknowledgments: The present work was the result of the master's thesis financed by Capes (Coordination of Improvement of Higher Level Personnel), foundation of the Ministry of Education of Brazil.

Author Contributions: Eleazar Chuchón and Augusto Pereira analyzed the data; Augusto Pereira contributed materials and analysis tools; Eleazar Chuchón wrote the article.

Conflicts of Interest: "The authors declare no conflict of interest." and "The founding sponsors had no role in the design of the study; in the collection, analyses, or interpretation of data; in the writing of the manuscript, and in the decision to publish the results".

Abbreviations

The following abbreviations are used in this manuscript:

TL: Titicaca Lake

CMORPH: Pacific Decadal Oscillation

CDC: CPC MORPHing technique

LT: Local Time

\section{References}

1. Choquehuanca, H. A.. Lago Titicaca, gran maravilla del mundo, 2011, 31.

2. Sanabria, J.; Marengo, J.; Valverde, M.; Paulo, S. Escenarios de Cambio Climático con modelos regionales sobre el Altiplano Peruano Departamento de Puno. Revista Peruana Geo Atmos férica, 2009, 149(1), 134-149.

3. Servicio Nacional de Meteorología e Hidrología Del Perú (SENAMHI). Escenarios Climáticos en el Perú para el año 2030, 2009a, 35.

4. Servicio Nacional de Meteorología e Hidrología Del Perú (SENAMHI). Escenarios de Cambio Climático con modelos regionales sobre el Altiplano Peruano (Departamento de Puno), 2009b, 134-149

5. Blanco, L. J.; Rosales, S.; Kim, H.; Son, S. Modelling Ecos ystem Carrying Capacity on Lake Titicaca. Spanish Agency for International development cooperation (AECID). 2010. 
The 1st International Electronic Conference on Hydrological Cycle (CHyCle-2017), 12 - 16 November 2017; Sciforum Electronic Conference Series, Vol. 1, 2017

6. Roche, M.A.; Bourges, J.; Cortes, J.; Mattos, R. Climatology and hydrology of the Lake Titicaca basin. in: Lake Titicaca. A syntl1esis of Limnological Knowleage (C. Dejoux \& A. litis eds.): 1992, 63-88, Monographiae Biologicae 68, Kluwer Academic Publishers.

7. Huang J., Guan X. \& Ji F. Enhanced cold-season warming in semi-arid regions. Atmos. Chem. Phys, 2012, 12, 5391-5398.

8. Huang J., Ji M., Liu Y., Zhang L. \& Gong D. An Overview of Arid and Semi-Arid Climate Change. Adv. Climate Change Res. 2013, 9, 9-14.

9. Joyce, R. J.; Janowiak, P. A.; Arkin, P.; Xie. CMORPH: A method that produces global precipitation estimates from passive microwave and infrared data at high spatial and temporal resolution. J. Hydromet., 2014, 5, 487-503.

10. Xue, M.; Droegemeier, K.; Wong, W.; Shapiro, A.; Brewster, K. Advanced Regional Prediction System Users Guide. University Oklahoma, USA. 1995, 380 pp.

11. Xue, M.; Wang, D.; Gao, J.; Droegemeier, K.; Brewster, K. The Advanced Regional Prediction System (ARPS), strom-scale numerical weather Prediction and data assimilation. Meteor. Atmos . Phycs, 2003, 82, 139-170.

12. Vemando F. Análise da circulación de brisa marítima e seus impactos sobre a precipitación na Región Metropolitana de Son Paulo por meido do modelo ARPS. Tese de Mestrado en Meteorologia. IAG/Universidad de Son Paulo. 2012.

13. Xin-xin, Z.; Xun-qiang, B.; Xiang-hui K. Observed Diurnal Cycle of Summer Precipitation over South Asia and East Asia Based on CMORPH and TRMM Satellite Data. Atmos Ocean Sci Lett (4):2015, 201-7.

14. Bowman K.P.; J. Craig C.; Noth G. R.; Wu Q,; Ha E.; Hardin J. Diurnal cycle of tropical precipitation in Tropical Rainfall Measuring Mission (TRMM) satellite and ocean buoy rain gauge data. J. Geophysical Research Atmos. 2005, Volume 110, Issue D21

15. Dai A.; Lin X.; Hsu K-L. The frequency, intensity, and diurnal cycle of precipitation in surface and satellite observations over low- and mid-latitudes. Clim Dyn, 2007, 29(7-8):727-44.

16. Mao J.; Wu G. Diurnal variations of summer precipitation over the Asian monsoon region as revealed by TRMM satellite data. Science China Earth Sciences 2012, Volume 55, Issue 4, pp 554-566

17. Wu, L.; Zhai P.Validation of daily precipitation from two high-resolution satellite precipitation datasets over the Tibetan Plateau and the regions to its east. Acta Meteorol Sin. 2012, (6):735-45.

18. Wetzel, R.G.; Manny, B.A. Diurnal changes in dissolved organic and inorganic carbon and nitrogen in a hardwater stream. Freshwat. Biol. 1973, 3:31-43.

19. Browning, K.A. Airflow and precipitation trajectories within severe local storms which travel to the right of the winds. J. Atmos. Sci. 1975, 21, 634-939.

20. Toth, J.; Johnson, R. H. Summer Surface Flow Characteristics over Northeast Colorado. Monthly Weather Review, 1985, vol. 113, issue 9, p. 1458

21. Tian, F.; Toon, O. B.; Pavlov, A. A.; Desterck H. A. Hydrogen - Rich Early. Earth Atmosphere, Science, 2005a, 308, $1014-1017$.

(C) 2017 by the authors; licensee MDPI, Basel, Switzerland. This article is an open access article distributed under the terms and conditions of the Creative Commons by Attribution (CC-BY) license (http://creativecommons.org/licenses/by/4.0/). 